KRYSTYNA SZELĄGOWSKA (Wydział Historii i Stosunków Międzynarodowych Uniwersytetu w Białymstoku)

https://orcid.org/0000-0002-5195-044X

\title{
Arilda Huitfeldta szlachecka wizja dziejów narodowych Danii*
}

Zarys treści: Celem niniejszego artykułu jest ukazanie, na tle uwarunkowań przemian historiografii, w jakim stopniu i w jaki sposób szesnastowieczna synteza dziejów Danii Arilda Huitfeldta odzwierciedla $\mathrm{z}$ jednej strony elementy występujących $\mathrm{w}$ epoce paradygmatów historiograficznych, z drugiej zaś - szlachecką perspektywę widzenia dziejów.

\begin{abstract}
This paper's primary objective is to show, in a general context of changes in historical writings, how the 16th century Chronicle of Denmark written by Arild Huitfeldt reveals the elements of the paradigms that had been developed at that time and in what ways it reflected the Danish nobility's perspective in interpreting the national past.
\end{abstract}

Słowa kluczowe: Historiografia XVI w., renesans, historiografia duńska, Arild Huitfeldt

Key words: Early modern historiography, Renaissance, Danish historiography, Arild Huitfeldt

W ewolucji historiografii duńskiej na początku czasów nowożytnych obserwujemy te same tendencje i kierunki, które występowały w dziejopisarstwie całej Europy, zwłaszcza krajów „,peryferyjnych”, tzn. tych, których nie objął bezpośredni wpływ Imperium Rzymskiego i jego kultury. Poczuciu wyższości, jakie emanowało z dzieł włoskich humanistów, podkreślających swą rolę w rozwoju cywilizacyjnym Europy i swoje związki z dziedzictwem antyku, przedstawianym jako niedościgły wzorzec, towarzyszyły różne deprecjonujące wypowiedzi na temat kultury narodów na północ od Alp albo znaczące milczenie. W XV w. upowszechniły się w Europie wypowiedzi, mające swój wzór w utworach Petrarki, wskazujące na przepaść między cywilizowaną Italią a barbarzyńską Północą - która to przepaść zresztą wyraźnie się powiększała: wojny włoskie bezpośrednio spowodowały, że do rodziny „barbarzyńców” dołączono Niemców ${ }^{1}$. Takie opinie wychodziły spod piór wielkich autorytetów epoki, jak Eneasz Sylwiusz Piccolomini ${ }^{2}$. Prowokowało to do działania autorów spoza Italii, należało bowiem pokazać własne dzieje, wskazać swoje miejsce w europejskim

* Niniejsza praca powstała w ramach realizacji grantu Narodowego Centrum Nauki, nr 2018/29/B/HS3/01023.

${ }^{1} \mathrm{C}$. H i r c h i, The Origins of Nationalism. An alternative History from Ancient Rome to Early Modern Germany, Cambridge 2012, s. 86-87, 152-153.

${ }^{2}$ H.-J. B ö m e 1 b u r g, Polska myśl historyczna a humanistyczna historia narodowa (15001700), tłum. Z. Owczarek, Kraków 2011, s. 75 n. 
kręgu cywilizacyjnym i własny wkład w jego rozwój. „Humanistyczne podkreślanie wybitnych włoskich tradycji wywoływało bardzo szybko u Francuzów, Niemców i Polaków - obok akceptacji istoty humanizmu - pytanie, czy istniały równorzędne, własne narodowe tradycje i w jakim stopniu zostały one właściwie ukazane z włoskiej perspektywy"3. Zdanie to można uzupełnić o przypadek skandynawski. Taka, często konfrontacyjna forma dyskursu kulturowego, także na płaszczyźnie historiografii, dała wielu badaczom, zwłaszcza podejmującym polemikę z tzw. modernistycznym modelem interpretacji dziejów narodu i świadomości narodowej, argumenty na rzecz obrony swojej tezy o istnieniu wczesnonowożytnego nacjonalizmu. Głosi ona, że już w tym okresie mamy do czynienia z myśleniem w kategoriach narodowych, a ówczesny nacjonalizm stawiał przed każdą wspólnotą, mającą polityczne aspiracje, konieczność podjęcia współzawodnictwa i walki nie tylko o znaczenie, ale i o narodowy honor ${ }^{4}$. I nie chodziło tylko o dosłowne starcia na polu bitewnym, ale także o własne osiągnięcia cywilizacyjne i kulturowe, które - subiektywnie przecież oceniane - dekretowano, autorytetem uczonych, jako lepsze ${ }^{5}$.

Wielkie przeobrażenia, które w Europie dokonywały się od co najmniej stulecia, skłaniały do stawiania pytań o tożsamość. Chodzi tu o załamanie uniwersalistycznego porządku i kształtowanie się dynastycznych państw narodowych - w tym kontekście najwyraźniej widać związek z procesem rozwoju poczucia narodowego - ale nie mniej znaczący był głęboki kryzys zachodniego chrześcijaństwa i Kościoła. Zwłaszcza od historiografii oczekiwano odpowiedzi, dla ustalania determinantów narodowości przeszłość własnego kraju i rodzimej wspólnoty była bowiem kluczowa. Na uwarunkowania europejskie zawsze nakładały się w tym przypadku lokalne przemiany. W odniesieniu do Danii i jej dziejopisarstwa było to objęcie władzy w połowie XV w. przez północnoniemiecką dynastię Oldenburgów, wykrystalizowanie się w drugiej połowie tego stulecia arystokratycznego konstytucjonalizmu, czyli idei będącej podstawą dla duńskiej wersji demokracji szlacheckiej (czy oligarchii magnackiej), a na początku XVI w. zaburzenia, związane z rozpadem unii kalmarskiej, reformacją i konfliktami społecznymi. Powiązanie tych ostatnich czynników dało w efekcie największy w dziejach Danii konflikt wewnętrzny: wojnę domową, zwaną wojną hrabską (grevefeiden).

W przypadku każdego europejskiego kraju w tej epoce inicjatywy historiograficzne, będące orężem w rywalizacji międzynarodowej, były powiązane z stanem stosunków z innymi krajami. W odniesieniu do Danii, zdradzającej wyraźne aspiracje mocarstwowe w regionie, silny impuls do podjęcia tego zadania wiązał się ze skomplikowanymi relacjami ze Szwecją, zarówno w zakresie czysto politycznym, jak i na płaszczyźnie naukowej ${ }^{6}$. Po bezpowrotnej utracie przez Danię władzy nad Szwecją i objęciu tam rządów przez Gustawa Erikssona stosunki te dalekie były od uspokojenia. Duńskie roszczenia i pragnienia odtworzenia unii, szwedzka pamięć o krzywdach i zbrodniach, jakich dopuszczali się Duńczycy zwłaszcza pod rządami

3 Tamże, s. 76.

4 Tamże, s. 2, 14, 95

5 Tamże, s. 98, 100.

${ }^{6}$ A. F r i i s, Nogle Betragtninger over Arild Huitfeldt og Danmarks Riges Krønike, w: Til Knud Fabricius, 13. August 1945, Kjøbenhavn 1945, s. 68. 
Chrystiana II, stwarzały napięcia, które znajdowały odbicie w sporach historyków (toczonych przecież na polityczne zlecenie) ${ }^{7}$.

Nie tylko jednak Szwedzi i ich narracja o cierpieniach i bezprawiu stanowiły problem. Drugim były stosunki z krajami niemieckimi i Cesarstwem. Na tej płaszczyźnie rozbieżności rysowały się trojakie: rywalizacja na terenie księstw Szlezwiku i Holsztyna, dominacja miast hanzeatyckich oraz twierdzenia niemieckich historyków, jakoby Dania w średniowieczu była lennem cesarskim. Niepokój budziła szeroka recepcja takich poglądów: powtarzał je np. w swoich tekstach Piccolomini ${ }^{8}$. W jego pracach Duńczycy mogli przeczytać o tym, że w średniowieczu Dania faktycznie uzależniona była od Lubeki: „Miasto to jest tak potężne i bogate, że trzy duże państwa, Dania, Szwecja i Norwegia powołują i usuwają swoich królów na jego skinienie". I drugi fragment, odnoszący się tylko do Danii: „Lubeka jest bardzo potężnym miastem. Bez jej pomocy duńscy królowie prawie nigdy nie byliby w stanie utrzymać swych poddanych w posłuszeństwie" . Takie zdania nie mogły się podobać, niezależnie od tego, że częściowo oddawały historyczną rzeczywistość. Źródłem dyskomfortu mogły stać się też dzieła niemieckiego historyka Alberta Krantza, bardzo skądinąd w Danii poważanego - król Chrystian III wsparł pośmiertne wydanie jego dzieła Chronica regnorum aquilonarium (wydanie niemieckie w Strasburgu 1545, łacińskie tamże 1546). Znaleźć w nich można było wiele informacji o krajach skandynawskich, problemem było jednak to, że Krantz opierał się na źródłach niemieckich i prezentował ich punkt widzenia, co budziło opór wśród patriotycznie nastawionych duńskich czytelników. Nie zmienia to faktu, że z kolei Gustaw Eriksson Waza narzekał na jego produńskie nastawienie ${ }^{10}$.

Nie mniej istotne było wszakże zapotrzebowanie wynikające z polityki wewnętrznej. W tym zakresie historiografia, poprzez wzmacnianie dumy narodowej, miała służyć legitymizacji państwa (przede wszystkim rządzącej dynastii) oraz stać się czynnikiem jego integracji. Uczeni z kręgu The Antiquarian Society w elżbietańskiej Anglii, grono dziejopisów pracujących na zlecenie cesarza Maksymiliana (żeby wymienić tylko Konrada Celtisa, 1459-1508) czy na gruncie polskim Filip Kallimach i Bernard Wapowski - to europejskie przykłady, z którymi zestawić można duńskie prace. W ich przypadku uprawomocnienia wymagało obalenie Chrystiana II, objęcie władzy przez boczną linię dynastii (młodszy brat Hansa, król Fryderyk w 1523 r.) i wszystkie kolejne jej działania. Także tutaj ważne były względy prestiżowe, pokaza-

${ }^{7}$ Dzieje tych szesnastowiecznych sporów zostały dość gruntownie przeanalizowane i opisane przez duńskich historyków, m.in. H. I1søe, Omkring Hans Svanings Refutatio og Chronicon Ioannis, Historisk Tidsskrift, ser. 12, 6, 1972, a ze starszej literatury: H. F. Rørd a m, Historieskrivningen og Historieskrivere i Danmark og Norge siden Reformationen, Kiøbenhavn 1867.

${ }^{8}$ M. v o n C o t t a - S c høn b e r g, Danmarksbillede hos en renæssancehumanist, Æneas Silvius Piccolomini (Pius II), w: Renæssancen i svøb. Dansk renæssance i europæisk belysning 1450-1550, Odense 2008, s. 99.

${ }^{9}$ Cyt. za: tamże, s. 96, 97.

${ }^{10}$ L. D a a, Nogle Bemaerkninger om Historieskriveren Albert Krantz, Historisk Tidsskrift, ser. 2, t. 5, 1886, s. 236, 257, 259; K. S k o v g a a r d - P e t e r s e n, Historiography at the Court of Christian IV (1588-1648). Studies in Latin Histories by Johannes Pontanus and Johannes Meursius, Copenhagen 2002, s. 92. 
nie światu duńskich osiągnięć naukowych i kulturowych, a także erudycji uczonych. Ukazanie pełnej chwały przeszłości miało spoić podzielone społeczeństwo i oddziałać na rozwijającą się świadomość narodową ${ }^{11}$. Norwescy historycy zauważają, że istotnym celem było też udowodnienie prawomocności duńskiego panowania nad Norwegią - zadanie dziejopisów miało polegać na ukazaniu, że Oldenburgowie są potomkami i dziedzicami dawnych norweskich władców ${ }^{12}$. Dodatkowym czynnikiem była adaptacja na gruncie duńskiej kultury nowej wizji dziejów rozwijającej się na tle przeobrażeń związanych z reformacją.

W całej ówczesnej Europie, wśród elit rosło zainteresowanie dziejami ojczystymi i historiografią. W zależności od kraju nasilenie tego procesu mogło przypaść na inny okres, np. w Polsce o wielkiej fali zainteresowań historią można mówić w latach 1550-1620, kiedy to objęła ona największe kręgi: nie tylko króla i dwór, ale też magnatów oraz przedstawicieli średniej szlachty ${ }^{13}$. Podobnie było w przypadku Danii. Pochodzące z XVI w. inwentarze oraz dokumenty spadkowe pokazują, że w bogatych skądinąd zbiorach książek duńskich magnatów znajdowały się liczne dzieła klasycznych autorów, w tym historyków, jak Ksenofont, Tukidydes, Polibiusz, Dionizy z Halikarnasu, Salustiusz, Cezar, Liwiusz, Tacyt, ale też z nowszych: Macchiavelli, Guiccardini, Sleidanus, Buchanan ${ }^{14}$. Zwraca także uwagę, jak chętnie w tym czasie duńscy magnaci pełnili rolę mecenasów, fundatorów i inicjatorów różnych pisarskich i wydawniczych inicjatyw w tym zakresie ${ }^{15}$. Nacisk na lekturę starożytnych historyków, postrzeganą jako przygotowanie młodej szlachty do udziału w życiu politycznych państwa, widoczny jest także w środowisku nauczycieli akademii rycerskiej w Sorø (założonej w 1586 r.) $)^{16}$.

Przełomowym dla duńskiej historiografii wydarzeniem była związana bezpośrednio z odrodzeniowymi kierunkami inicjatywa Christierna Pedersena (ok. 1448 - 1554), łacinnika, teologa i wydawcy, który w trakcie pobytu w Paryżu na początku XVI w. doprowadził do wydania kroniki Saksona Gramatyka. Ukazała się w 1514 roku pod tytułem: Danorum regum heroumque historie stilo eleganti a Saxone Grammatico natione Sialandico necnon Roskildensis ecclesie preposito abhinc supra trecentos annos conscripte et nunc primum literaria serie illustrate tersissimeque impresse. Publikacja wpisywała się w europejski trend wydawania drukiem średniowiecznych dzieł historycznych, które opowiadały o najdawniejszych dziejach narodowych i ukazywały wielkość i chwałę ojczyzny w czasach skądinąd deprecjonowanych przez włoskich humanistów. Stanęła więc obok takich osiągnięć, jak druk Geoffreya Monmoutha, Grzegorza z Tours czy Liutpranda z Cremony, nieco później Jordanesa,

${ }^{11}$ K. S k o v g a a r d - P e t e r s e n, Historiography, s. 13, 92.

$12 \varnothing$. R i a n, Historie i tvangstrøye. Kongemakt og historieformidling i Danmark-Norge 1536-1814, Historisk tidsskrift [norw.] 92, 2013, s. 66, 85.

${ }^{13}$ H.-J. B ö m e 1 b u r g, Polska myśl, s. 167.

14 E. J ørge n s e n, Historieforskning og Historieskrivning i Danmark indtil Aar 1800, København 1931, s. 63-64.

${ }^{15}$ W tym kontekście wymienia się takich dygnitarzy, jak Johan Friis, Niels Kaas, Christopher Valkendorff, Herluf Trolle.

${ }^{16} \mathrm{~W}$ przeciwieństwie do miejskich szkół łacińskich, powstających po reformacji, do których uczęszczała młodzież mieszczańska (Dansk litteratur historie, t. II, Gyldendal 1984, s. 318). 
Pawła Diakona i Einharda, zyskała też uznanie samego Erazma z Rotterdamu ${ }^{17}$. Już w tytule Pedersen informował o narodowości autora (nazywając go Zelandczykiem, za średniowiecznym odpisem Gesta, choć faktycznie nie ma potwierdzenia, by Sakso pochodził z Zelandii) oraz podkreślał jego piękną łacinę.

Jednakże dzieło Gramatyka, doprowadzone do końca XII w. domagało się dalszego ciągu, ale też przybliżenia: „Przetłumaczenie i kontynuacja Saksona stały się zadaniem dla kilku pokoleń" - pisała Ellen Jørgensen ${ }^{18}$. Wkrótce okazało się, że podobnie jak w ówczesnej Polsce, zadanie napisania nowej syntezy dziejów ojczystych jest bardzo trudne. Mamy w przypadku Danii cały szereg wybitnych skądinąd uczonych, którzy przez półwiecze nie zdołali stworzyć łacińskiej historii Danii, łączącej kontynuację Saksona z nowoczesnym ujęciem, zgodnym z wymogami epoki. Nie startowali od zera, trwały już bowiem prace nad gromadzeniem źródeł (reformacja oddała państwu liczne zbiory kościelne) oraz były podejmowane różne przedsięwzięcia pisarskie. Rękopiśmienne, niedrukowane fragmenty były przekazywane, często po śmierci autora, na polecenie króla kolejnym historykom. Teksty przepisywano lub streszczano i dzięki temu ich treść częściowo się zachowała. Zadanie stworzenia nowoczesnej syntezy dziejów Danii powierzano w drugiej połowie XVI w. kolejno takim uczonym, jak Hans Svaning (1503-1584), Anders S. Vedel (1542-1616), Niels Krag (1550-1602). Żaden jednak pracy nie sfinalizował, mimo że utworzony został nawet urząd historiografa królewskiego (1594).

Trudności w stworzeniu syntezy były zapewne z jednej strony efektem nadmiernych ambicji historyków, którzy - jak Vedel - snuli nierealistyczne plany, ale też pewnej niekonsekwencji państwa, które albo nie udzielało uczonym odpowiednego wsparcia, albo - jak w przypadku Nielsa Kraga - obarczało ich innymi obowiązkami. Np. Vedlowi, mimo starań, nie udało się uzyskać urzędowej rekomendacji królewskiej do penetrowania bibliotek klasztornych, jaką otrzymywali w tym czasie np. historycy angielscy ${ }^{19}$.

Dokładne omówienie nieudanego procesu tworzenia narodowej syntezy w szesnastowiecznej Danii wykracza poza ramy tego artykułu, wspomnieć jednak należy, że jest to interesujący przykład zaangażowania ówczesnego państwa w tworzenie dzieła historycznego. Tak, jak w całej Europie, pisanie historii bez wątpienia było traktowane jako przedsięwzięcie państwowe, o wielkiej wadze politycznej ${ }^{20}$. Celowo piszę o państwie, ponieważ w grę wchodziła aktywność urzędników państwowych, którzy czuwali nad pracą historyków, zwłaszcza jeśli chodzi o zgromadzone materiały, uznane przecież za własność Korony i przekazywane kolejnym uczonym. Znaczący udział w przedsięwzięciach mieli najważniejsi dygnitarze i bliscy współpracownicy kolejnych monarchów, kanclerze Johan Friis (1494-1570) i Niels Kaas (1535-1594). Do ich służbowych obowiązków należały nie tylko bezpośrednie kontakty, ale też lektura napisanych tekstów oraz pierwsza ocena i decyzja, czy pracę skierować do cenzury urzędowej, wykonywanej przez profesorów Uniwersytetu

17 Tamże, s. 321.

${ }^{18}$ E. Jørg e n s e n, Historieforskning, s. 63: „At oversætte og fortsætte Saxe blev Opgaven i et Par Slægtled".

19 J. E v a n s, A History of the Society of Antiquaries, Oxford 1956, s. 5.

${ }^{20}$ K. S k o v g a a r d - P e t e r s e n, Historiography, s. 96. 
Kopenhaskiego ${ }^{21}$. Nie mamy w przypadku Danii takiego „ręcznego” sterowania historykami, jakie uprawiał w tym czasie w Szwecji Gustaw Eriksson, który nie tylko przydzielał zadania, ale też dostarczał materiały, dokładne wskazówki oraz informacje, które uznawał za konieczne. Były to ingerencje tak daleko idące, że o pewnych historykach, jak Peder Svart, można mówić, że byli redaktorami, a nie autorami. Nadmierna samodzielność dziejopisa mogła się dla niego źle skończyć, o czym przekonał się Olaus Petri, którego Svenska Krönecka, a konkretnie aluzje do tyrańskich rządów, wzbudziła atak wściekłości króla i została zakazana ${ }^{22}$. Również jednak w Danii nasilała się ingerencja państwa, zwłaszcza od momentu objęcia władzy przez młodego Chrystiana IV (1596). Kiedy w 1593 r. królewski historiograf Niels Krag wydał łacińskie dzieło poświęcone Sparcie, słynny astronom Tycho de Brahe (1546-1601), który miał wkrótce osobiście doświadczyć niełaski monarchy, napisał wiersz, w którym pytał historyka, dlaczegoż to, zamiast opiewać czyny przodków, pisze o Spartanach. I odpowiadał sobie melancholijnie: Tak jak pożyteczne jest poznawanie naszej własnej przeszłości, tak niebezpieczne jest pisanie o niej... ${ }^{23}$.

Zadanie stworzenia oficjalnej historii Danii po łacinie wypełnili dopiero w XVII w. powołani przez Chrystiana IV uczeni Johannes Isaius Pontanus (1571-1639) oraz Johannes Meursius (1579-1639) ${ }^{24}$. Choć ich prace były znane za granicą i stały się źródłem wiedzy o dziejach Danii w Europie (korzystał z nich np. Hugo Grotius, przygotowując nowe wydanie dzieła $\mathrm{O}$ prawie wojny i pokoju ${ }^{25}$, to ich wkład w rozwój duńskiej historiografii jest w sumie niezbyt istotny. Po pierwsze, obie próby były mało samodzielne - opierały się na rodzimym dorobku, poczynając od Saksona, a na pracach nowożytnych kończąc. Co ważniejsze jednak, zostały wyparte ze świadomości społecznej przez epokowe dzieło Arilda Huitfeldta, duńskojęzyczne dziewięciotomowe dzieje Danii, stworzone przez autora na marginesie wszystkich starań państwa o doprowadzenie do powstania „kontynuacji Saksona”.

W duńskiej historiografii co prawda brakuje nieco wielkich syntez dziejów tej nauki - właściwie do tej pory jedyną pozostaje klasyczna już praca Ellen Jørgensen ${ }^{26}$, niemniej jednak Huitfeldt budził i nadal budzi zainteresowanie. Poważne, nadal

${ }^{21}$ Tamże, s. 96; H. I 1 s ø e, Historisk censur i Danmark indtil Holberg, Fund og Forskning 20, 1973, s. 47, 49. T. D a m s h o 1 t, Den nationale magtstat 1560-1760, w: Danmarks historie, t. X, red. S. Mørch, København 1992, s. 53-54; Ø. R i a n, Historie, s. 74.

${ }^{22}$ L. O. L a r s s o n, Gustaw Waza. Ojciec państwa szwedzkiego czy tyran?, tłum. W. Łygaś, Warszawa 2009, s. 52, 83, 378, 380, 411.

${ }^{23}$ P. A. Vin i landi c u s, Nordens gotiske storhedstid, Syddansk universitetsforlag, Odense 2012, s. 706.

${ }^{24}$ Obaj niezależnie od siebie stworzyli dwa dzieła: Pontanus - Rerum Danicarum historia (t. I do 1448 r., wyd. 1629), Meursius - Historiae Danicae libri tres, in quibus res commemorantur gestae a Christiano I ac Joanne eius filio et nepote Christiano II (1630), co stanowiło kontynuację pracy Pontanusa. Dogłębną analizę tych dzieł dała ostatnio K. S k o v g a a r d - P e t e r s e n, Historiography.

25 Tamże, s. 13.

${ }^{26}$ Lukę te zapełnia do pewnego stopnia ostatni tom syntezy dziejów Danii (Danmarks historie, t. X, 1992), poświęcony przeglądowi dziejopisarstwa od średniowiecza poczynając, w którym autorzy starają się połączyć dogłębną informacje o dziejopisach i ich dziełach z charakterystyką przeobrażeń myślenia o dziejach. 
wykorzystywane, studium biograficzne o nim napisał pod koniec XIX w. Holger F. Rørdam ${ }^{27}$. Po drugiej wojnie światowej ważnym badaczem szesnastowiecznej historiografii i kultury duńskiej był Harald Ilsøe ${ }^{28}$. W latach sześćdziesiątych i siedemdziesiątych uczestniczył on w realizowanym na Uniwersytecie w Kopenhadze przedsięwzięciu badawczym dotyczącym Huitfeldta i prac historycznych w XVI w. ${ }^{29}$ Bohater tych badań był postacią w dziejach Danii ważną i uważa się go za głównego przedstawiciela historiografii wczesnonowożytnej, który wywarł ogromny wpływ na duńską kulturę, ale znany i czytany był w całej Skandynawii ${ }^{30}$. Wpływ jego dzieła historycznego wykraczał poza sferę nauki i kultury: przy różnych inicjatywach politycznych w XVII w. przywoływano autorytet tego historyka i jego wypowiedzi, jak np. w kontekście debat na reformą wojska ${ }^{31}$. Ten dziejopis i mąż stanu w Polsce pozostaje właściwie nieznany, nie wymienia go nawet wielka synteza Andrzeja F. Grabskiego ${ }^{32}$. A tymczasem dorobek Huitfeldta powinien być także interesujący dla polskich historyków, jako że, jak zobaczymy, reprezentuje on tzw. szlachecką wizję dziejów, która odzwierciedlać miała rolę szlachty i jej przodującą pozycję w społeczeństwie. Nasuwają się więc naturalne skojarzenia z sarmacką koncepcją dziejów Polski.

Arild Huitfeldt (1546-1609) pochodził z rodziny szlacheckiej, która należała do wyższej warstwy tego stanu. Odebrał staranną edukację, łącznie z podróżą zagraniczną, w trakcie której studiował w Strasburgu, Tybindze, Orleanie, stykając się z między innymi takimi uczonymi, jak niemiecki humanista Johannes Sturm (1507-1589) czy szlezwicki prawnik i historyk Paul Cypraeus (1536-1609). Po powrocie Huitfeldt otrzymał w 1571 r. stanowisko sekretarza w duńskiej kancelarii królewskiej, co także było dość typowym etapem kariery syna szlacheckiego w służbie państwa. Pracując na tym urzędzie, uzyskał dostęp do najrozmaitszych archiwaliów, co być

${ }^{27}$ H. F. Rørd a m, Historieskriveren Arild Huitfeldt, Danmarks Riges Kansler og Raad, Skoleherre for Herlufsholm, Kjøbenhavn 1896

${ }^{28}$ H. I $1 \mathrm{~s} ø$ e, En redegørelse for Arild Huitfeldts alment litterære læsning og åndhistorisk baggrund således som det kan læses ud af hans fortaler til Danmarks Riges krønike og hans kommenterende bemærkninger i selve dennes tekst, København 1955; t e n ż e, Arild Huitfeldts Krønike, konfronteret med Anders Sørensem Vedel og eftertiden, Fund og Forskning 14, 1967.

${ }^{29}$ Np. H. I 1 s ø e, Svaning, Vedel, Huitfeldt og Krag, w: Tradition og kritik. Festskrift til Svend Ellehøj den 8. september 1984, København 1984.

${ }^{30}$ K. S k o v g a a r d - P e t e r s e n, Historiography, s. 114. T. D a m s h o lt, Den nationale magtstat, 59; Å. H e r m a n s s o n, Karl IV och ständerna. Tronfrågan och författningsutvecklingen i Sverige 1598-1611, Uppsala 1962; w aneksie do tej monografii, autor umieścił (jako Ekskurs 5) studium poświęcone myśli politycznej Huitfeldta (Arild Huitfeldt och monarchomacherna, s. 306-315). Natomiast H. I 1 s ø e, Arild Huitfeldts Krønike, s. 42, zwrócił uwagę, że temuż Karolowi IX, który zakupił tom poświęcony Chrystianowi III, bardzo nie spodobał się sposób, w jaki Huitfeldt opisał jego ojca, Gustawa Erikssona.

${ }_{31}$ Tamże, s. 40.

32 A.F. Grabski, Dzieje historiografii, Poznań 2003. Bardzo skrótowo (trzy zdania) Huitfeldta omówił E. M i e r z w a, Historia historiografii, t. II, Warszawa 2007, s. 286, który popełniał zresztą błędy. Krótką wzmiankę dał też Z. C i e s i e ls k i, Dzieje kultury skandynawskiej, t. I, Gdańsk 2016, s. 343. Huitfeldta uwzględnił ostatnio P. Migdals k i, Słowiańszczyzna północno-zachodnia w historiografii polskiej, niemieckiej i duńskiej, Wodzisław Śląski 2019, s. 95-97. 
może zapoczątkowało gromadzenie materiałów, które mógłby wykorzystać w pisaniu dzieł historycznych ${ }^{33}$. Wkrótce Huitfeldt został awansowany na urząd nadsekretarza, zaś w 1586 r. król Fryderyk II mianował go kanclerzem Korony, co dawało mu też miejsce w Radzie Królestwa, czyli instytucji rządzącej wraz z królem państwem. Za panowania nowego monarchy, Chrystiana IV, Arild Huitfeldt należał do wąskiego kręgu magnatów wywierających bezpośredni wpływ na rządy (powierzano mu zwłaszcza misje dyplomatyczne). Drugą sferą publicznej aktywności Huitfeldta było kierowanie szkołą dla młodej szlachty w Herlufsholm na Zelandii, założoną zresztą przez jego wuja, admirała Herlufa Trolle (istnieje do dziś). Był jej zarządcą w latach 1583-1586.

Przy tym ogromie obowiązków administracyjnych Huitfeldt zdołał w ciągu ośmiu lat napisać dziewięć tomów dziejów Danii, a do tego dziesiąty, poświęcony historii jej Kościoła, wszystkie w formacie in quarto. Wcześniej, jak już wspomniano, miały miejsce dwie nieudane próby stworzenia syntezy dziejów duńskich, podjęte przez Svaninga i Vedla. Niels Krag sprawował już co prawda urząd królewskiego historiografa, ale jego praca na pewno musiała potrwać. Mający zaś duże zbiory Huitfeldt uznał, że szkoda tracić czas (wedle ówczesnych kryteriów był już wszak człowiekiem leciwym), tym bardziej, że oficjalne plany mówiły o łacińskiej historii Danii przeznaczonej dla zagranicy, a Huitfeldt chciał pisać dla rodaków. Podjął jednak to samo zadanie, które zlecono Kragowi: napisanie dziejów panowania ostatnich dwóch monarchów. Nie tylko mu się to udało, ale praca rozrosła się do ogromnej, całościowej syntezy ${ }^{34}$.

Dzieło - podobnie jak kronika Saksona - powstawało w całkowitym oderwaniu od dziejowej chronologii. Autor posuwał się do tyłu, w głąb dziejów, a do tego nie zawsze konsekwentnie. Zaczął (w 1595 r.) od panowania Chrystiana III (1536-1559), czyli dziadka panującego monarchy. W następnym tomie, wydanym rok później, przedstawił panowanie Chrystiana II (1513-1523), zaś w 1597 r. ukazał się tom poświęcony Fryderykowi I (1523-1533). Dwa tomy o pierwszych Oldenburgach (Chrystian I 1448-1481 i Hans 1481-1513) wyszły w 1599 r. Te pięć tomów, przedstawiających dzieje panowania dynastii Oldenburgów, nosiło tytuły w formie: Krótki historyczny opis ważnych [wydarzeń], które zdarzyły się za panowania... ${ }^{35}$. Następne trzy tomy miały uzupełnić lukę, jaka powstała między zakończeniem kroniki Saksona, a objęciem tronu przez Oldenburgów. Autor nadał im tytuł: Chronologia, czyli kontynuacja naszej duńskiej historii od śmierci Saksona. Pierwszy (czyli w ciągu szósty) tom obejmuje czasy od Kanuta VI do Eryka Glippinga (wyd. 1600), drugi (siódmy) od Eryka Menveda do Waldemara Atterdaga (1601), zaś trzeci (ósmy) od Olafa Håkonssona do śmierci Krzysztofa Bawarskiego (1602). Obejmują zatem lata 1182-1448 i są ustawione w chronologicznym porządku. Huitfeldt domknął całość (1603) tomem, będącym „streszczeniem” i przeróbką Gesta Danorum Saksona, czyli

${ }^{33}$ H. F. Rør d a m, Historieskriveren, s. 48.

${ }^{34}$ Dla porządku dodajmy, że Huitfeldt miał na swym koncie także inne intelektualne osiągnięcia, przede wszystkim wydanie Leges provinciales terrae Scaniae (1590) czy Den norske Hirdskraa (1594).

${ }^{35}$ En kaart historiske Beskriffuelse, paa hues merckeligt, som sig aarlige onder Kong Christian den Tredie, Danmarckis, Norgis, Vendis oc Gottis Konning, etc. haffuer tilldragit, 1595. 
omówieniem czasów od legendarnego króla Dana do Kanuta VI. Ostatni tom, wydany w 1604 r., nosił tytuł Kronika biskupów i jest chronologicznym wykazem biskupów Kościoła duńskiego. Wydanie to, obecnie dość rzadkie (reprint wydano w latach 1976-1978), wydrukował, najpewniej na koszt autora, Matz (Mogens) Vingaard, ale na całości nie podano autora - Huitfeldt w swej skromności uważał się zaledwie za „narzędzie wykonania zadania, którego - - się podjął”36. Jako kanclerz Korony był natomiast w tym szczęśliwym i wyjątkowym położeniu, że nie musiał martwić się o cenzurę i jej ingerencje ${ }^{37}$.

Ze względu na dużą popularność dzieła Huitfeldta ${ }^{38}$, w połowie XVII w. powstał plan wydania jego wznowienia. Dzieje Danii w porządku chronologicznym, w dwóch tomach in folio (przyjęto ciągłą paginację ponad półtora tysiąca stron) zostały wydane pod tytułem: Kronika Królestwa Duńskiego ${ }^{39}$, który odtąd funkcjonuje na oznaczenie dzieła Huitfeldta. Data tej publikacji stwarza problemy: na stronie tytułowej tomu I widnieje rok 1652, przedmowa datowana jest na 1653, zaś na ostatniej stronie tomu II umieszczono informację, że wydrukowano go w 1655 r. Znany jest list z 1654 r. z informacją, że Kronika właśnie się ukazała ${ }^{40}$. To paradne wydanie, jak głosi informacja na stronie tytułowej, zostało sfinansowane przez wydawcę, Joachima Moltke (zm. 1661), który od 1628 r. prowadził w Kopenhadze księgarnię i wydawnictwo, stając się najpoważniejszym przedsiębiorcą tej branży w kraju ${ }^{41}$. On też podpisał się pod przedmową-dedykacją dla panującego wówczas Fryderyka III, choć wątpi się, aby rzeczywiście był autorem ${ }^{42}$. Narrację poprzedzał szereg władców: po imiennej liście królów Danii od Dana do Waldemara Zwycięskiego, czyli bohaterów kroniki Saksona, umieszczono portrety wszystkich panujących, tym razem aż po współczesnego Fryderyka III. Poza tymi rysunkami, w książce jest jeszcze portret autora, a na bogatej w barokowe ornamenty stronie tytułowej - u góry portret Fryderyka III, w środkowej części, po dwóch stronach kartusza z tytułem dzieła, wizerunki Dana i Chrystiana IV, poniżej zaś rysunek nawiązujący do opowieści o tym, jak to biskup Poppo przekonał króla Haralda Sinozębego i jego drużynę do przyjęcia chrztu. Dzieło obejmuje też sążnisty indeks (głównie osobowo-rzeczowy) oraz erratę.

${ }^{36}$ H. F. Rørd a m, Historieskriveren, s. 158.

${ }^{37}$ H. I $1 \mathrm{~s} ø$ e, Historisk censur, s. 47; T. D a m s h o lt, Den nationale magtstat, s. 83.

${ }^{38}$ Faktycznie po 25 latach nakłady były już wyczerpane (H. I1 s ø e, Arild Huitfeldts Krønike, s. 24).

${ }^{39}$ Danmarckis Rigis Krønicke ved Arrild Huitfeld ved Obersberg, [t. I:] Den første Tomus eller Part Aff Danmarckis Rigis Krønicke fra Kong Dan til den høylofflige Oldenburgiske Stamme, Kiøbenhaffn 1652 (dalej cyt.: DRK I); Den Anden Tomus eller Part aff Danmarckis Rigis Krønicke, angaaende dend høylofflige Oldenburgiske Stamme, Kiøbenhaffn 1652 (dalej cyt.: DRK II); dostępne online: $<$ https://archive.org $>$.

${ }^{40}$ H. F. Rørd a m, Historieskriveren, s. 304.

${ }^{41}$ L. N i e 1 s e n, Joachim Moltke, w: Dansk biografisk Leksikon, Gyldendal 1979-1984, online: $<$ https://biografiskleksikon.lex.dk/Joachim_Moltke>.

${ }^{42}$ H. F. Rør d a m, Historieskriveren, s. 304. Przypuszcza on, że autorem mógł być teolog Jesper Brochmand (1585-1652) albo Vitus Bering (1617-1675) - co bardziej prawdopodobne, ze względu na wiek i zawód (Bering był historykiem), choć dorobek miał niewielki. Wątpliwości H. F. Rørdama brały się z faktu, że przedmowa jest w istocie rozprawką metodologiczną. 
Przyjęty tytuł był odpowiedni, bowiem praca w wielu miejscach przypomina kronikę i to w najprostszej formule, zbliżonej do rocznika. Taki charakter ma pierwszy/ ostatni tom - przeróbka Huitfeldta polegała na „wyjęciu” z Saksona konkretnych faktów i wydatowaniu ich. Stwierdzając, że najważniejsze było dla niego chronologiczne uporządkowanie tekstu kronikarza, Huitfeldt wpisywał się we współczesny sobie trend historiografii. W wielu dziełach średniowiecznych, i dotyczy to także Gesta Danorum, podawano raczej daty dzienne niż roczne, co nie było bynajmniej zabiegiem technicznym, ale wynikało z przyjętej koncepcji dziejów jako dzieła Bożego i historii jako dostarczycielki wzorców i przykładów, opisującej nie to co przemija, ale to, co trwa ${ }^{43}$. Podejście to zaczęło zmieniać się w renesansie, kiedy wraz z pojawieniem się myślenia historycznego rosło znaczenie chronologii jako odrębnej dyscypliny, wymagającej wszechstronnej wiedzy i erudycji oraz krytycznej wnikliwości ${ }^{44}$. Huitfeldt stosował system liczenia dat od narodzenia Chrystusa, przeprowadzając uczone analizy i przywołując różne autorytety, zwłaszcza Achillesa Gassera $^{45}$. W duchu renesansowego krytycyzmu usuwał także materiał baśniowy. Sceptycznie odniósł się wielu legendarnych duńskich władców wymienianych przez średniowiecznego kronikarza, uznając, że część z nich panowała równolegle. Próbował także rozplątać zawikłaną chronologię najdawniejszych dziejów Danii. Opis dawnych panujących, oparty na materiale Saksona, niekiedy weryfikowany innymi autorami, jak Adam z Bremy, przechodził w formę rocznikarską. Jak w średniowiecznych annałach wydarzenia polityczne różnej wagi przeplatają się z tu informacjami o klęskach naturalnych czy dziwach przyrody. Wydaje się, że ta część jest najmniej samodzielna - starzejący się i schorowany Huitfeldt przypuszczalnie wspomagał się w tej pracy sekretarzami i kopistami, a jakość ich pracy była różna ${ }^{46}$. W tomach Chronologii rozbudowana narracja pojawia się na większą skalę, podobnie jak wstawione dokumenty, akty, traktaty, przeważnie przetłumaczone z łaciny na duński. Takie ujęcie nasila się $\mathrm{w}$ częściach ostatnich (opracowywanych jako pierwsze), poświęconych dynastii oldenburskiej - to, co było dla czytelników najciekawsze, zostało napisane najbardziej nowocześnie i zarazem jest to najbardziej samodzielna część Kroniki.

Utylitarne (wychowawcze i dydaktyczne) walory dzieła historycznego były dla Huitfeldta oczywiste: „stąd biorą się świecka wiedza i doświadczenie”, jak pisał znany mu doskonale Philippe de Commines ${ }^{47}$. Takie ujęcie wynikało z przywiązania do modelu historii jako skarbnicy przykładów oraz z przyjęcia renesansowej perspektywy czasu jako powtarzającego się cyklu, dzięki któremu nauki z przeszłości są zawsze aktualne. Towarzyszyło temu przekonanie, że ludzka natura jest niezmienna.

${ }^{43}$ K. P o m i a n, Przeszłość jako przedmiot wiary, Warszawa 2009, s. 166-167.

${ }^{44}$ A. Grafto n, Worlds made by Words. Scholarship and Community in the Modern West, Harvard 2011, s. 27-28.

45 Achilles Pirmin Gasser (1505-1577), niemiecki uczony, astrolog, autor m.in. Historiarum et Chronicorum totius mundi epitome, Basileae 1532, gdzie zastosował podwójną datację, zarówno od stworzenia świata (lewy margines) jak i od narodzenia Chrystusa (prawy margines). Np. Gothermus Daniae rex widnieje przy: annus mundi 4714 oraz an. ante Christum 485 (s. 46).

${ }^{46}$ J. Kanstrup, Huitfeldts fremstilling af Christoffer II's tilbagekomst til Danmark, Historisk Tidsskrift, ser. 12, t. 6, 1972, s. 119.

${ }^{47}$ Cyt. za: H. I $1 \mathrm{~s} ø$ e, Arild Huitfeldts, s. 24. 
„To, co się zdarzyło kiedyś, zdarza się teraz: stale rozgrywa się ta sama gra i ten sam dramat, tylko osoby się zmieniają; co stało się tysiąc lat temu, dzieje się teraz, jako że człowiek zawsze myśli jednakowo"48. Podobne ujęcie przedstawiał A. Vedel we wstępie do swojego przekładu Saksona: „Jest bowiem tak, że wszystko to jest grą, która zawsze toczy się na tym świecie. Zmieniają się osoby i ludy. Lecz tak, jak jedna jest ludzka natura, zawsze taka sama w swej istocie i zwyczajach, tak samo [jednakowa jest] w uczynkach, zasadach, zamiarach, szczęściu, klęskach, powodzeniu, zdarzeniach, upadku i postępach, we wszystkich działaniach" ${ }^{49}$. Ogromne podobieństwo obu fragmentów może wskazywać na zapożyczenia, ale z drugiej strony występują tu bardzo konwencjonalne zwroty, typowe dla renesansowego myślenia o historii zawarte np. w świetnie znanych wówczas pracach Nicolo Macchiavellego.

Huitfeldt kierował swoją pracę do młodego monarchy, którego chciał „nauczyć” sztuki polityki. Rozpoczęcie opisem panowania Chrystiana III, dziadka panującego, miało na celu ukazanie pozytywnego przykładu; kolejnym krokiem było ukazanie skontrastowanego z nim przykładu negatywnego, czyli portretu Chrystiana II $^{50}$. Większość nauk zawarł historyk w poprzedzających każdy tom przedmowach-dedykacjach dla Chrystiana IV, w których wykładał swoje poglądy na różne kwestie ustrojowe, polityczne, ale też moralne i religijne. W wielu przypadkach autor był konsekwentny i jego poglądy rzutowały na ujęcie konkretnych historycznych zdarzeńn ${ }^{51}$. Zarysowała się nieco inna niż dawniej perspektywa. Np. A. Vedel pozostający, podobnie jak wcześniej Svaning, pod wpływem historiozofii Filipa Melanchtona (ukazanej w jego przeróbce Kroniki Cariona), podkreślał cele moralizatorskie, nasycając je jednocześnie treściami religijnym ${ }^{52}$. U Huitfeldta natomiast nacisk jest położony raczej na dydaktyczne cele historii, postrzeganej jako „mistrzyni polityki” - autor thumaczył królowi zasady ustrojowe Danii, pokazując na historycznych przykładach szkodliwość ich łamania, przypominał, że władcy właśnie z dziejów, najlepiej ojczystych, nabyć mogą doświadczeń i poznawać zasady sprawowania władzy ${ }^{53}$. Historia ma nauczać

${ }^{48}$ DRK I, s. 137-137: „Thi deraf fødis weltlig Forfarenhed og Forstand. Huad som er skeed, tilforne skeer endnu: altig leegis samme Leeg og Tragaedie ved andre Personer: huad som er skeed for tusind Aar skeer endnu: Mennisken er altid ens sindet"; zob. też s. 294.

49 A.S. Ve d e 1, Fortale, w: Den danske Krønike af Saxo Grammaticus, ovesat af Anders Sørensen Vedel, wyd. C. F. Wegener, Kiøbenhavn 1851, s. 14: „Thi det gaar io saaledis til, at det er alt it Spil, som altid driffuis udi denne Verden. Personerne oc Folcket forandris alene. Men ligeuis som Menniskelig natur, den er en, oc sig selff altid lig paa sin Art oc skick, saa ocsaa met all handel oc vandel, Raad, Anslag, Lycke, Modgang, Metgang, hendelse, fald oc fremgang, udi all bestilling".

50 Dansk litteratur historie, t. II, s. 439.

51 A. F r i i s, Nogle Betragtninger, s. 76.

52 A.S. Ve d e 1, Fortale, s. 1-2; Johann Carion (1499-1537), niemiecki dziejopis i astrolog; jego Chronica durch M. Johan. Carion vleissig zusamen gezogen, meniglich nützlich zu lesen, została wydana w 1531 r., ale największy rozgłos zyskała łacińska przeróbka wykonana przez Melanchtona i jego zięcia, Caspara Peucera (1525-1602), wydana po raz pierwszy 1558-1560. Tłumaczenie duńskie (tłum. Jon Turson) wydane zostało w 1554 r. (Chronica M. Johan Carion paa thet flittigste sammen dragen). Głęboko prowidencjalistyczna, ukazująca dzieje jako drogę do protestanckiego wyzwolenia i oczyszczenia chrześcijaństwa, niosła także wyraźnie przesłanie moralizatorskie (K. S k o v g a a r d - P e t e r s e n, Historiography, s. 98-100, 108).

${ }^{53}$ DRK I, s. 137. 
roztropności (prudentia), jako sztuki dobrego rządzenia. Stąd niezbędną kwalifikacją historyka jest umiejętność przedstawiania politycznego osądu (politicum iudicium), którego zresztą w pracy, jak zobaczymy, nie brakuje ${ }^{54}$. W tym programie edukacyjnym zmieściły się również uwagi na temat obowiązków monarchy wobec instytucjonalnej religii oraz rozważania nad wyższością armii narodowej nad zaciężną ${ }^{55}$.

Treści moralizatorskie, unaoczniające tradycjonalizm historyka, są dyskretniejsze, choć i tu nie obyło się bez odniesień religijnych, bowiem autor w wielu przypadkach interpretował różne klęski jako kary Boże za występki, zarówno królów, jak i całego narodu ${ }^{56}$. Innego rodzaju moralistyka dotyczy, w bardzo klasyczny sposób, przywołujący na myśl Liwiusza, spraw obyczajowych. Mamy skargi na nowe obyczaje, na odchodzenie od skromnego i pobożnego stylu życia ojców, na pychę bliźnich, której dowodzą wystawne obyczaje funeralne ${ }^{57}$. Te poglądy z jednej strony wiążą się z rosnącą potęgą szlachty, która za pomocą architektonicznego i artystycznego rozmachu demonstrowała swoją pozycję, z drugiej zaś z walką państwa z tymi tendencjami: król Fryderyk II próbował utemperować te skłonności reskryptem z 1562 r. zakazującym szlachcie budowania zbyt okazałych grobowców.

Chrześcijańska optyka jest w dziele Huitfeldta słabo zaznaczona. Mało jest przywoływania woli Opatrzności, pouczające zwroty mają w dużej mierze charakter konwencjonalny i wyrastają raczej z własnej religijności i pobożności niż z przemyślanej koncepcji dziejów. Racjonalnie ukazany jest też sam proces przyjęcia chrześcijaństwa. U Huitfeldta trudno znaleźć nawet dokładną i wyeksponowaną informację na ten temat. Odpowiedni zapis brzmi szczególnie: „Następnie cesarz Henryk na czele armii ruszył na Danię w roku 934 - -. Król Gorm tak się wystraszył, że natychmiast obiecał zrobić wszystko, co mu nakaże i wprowadził chrześcijaństwo do swego królestwa". Dalej autor opisuje natomiast politykę następcy, czyli Haralda Sinozębego, który nie tylko przyjął chrzest, ale sprowadził misjonarzy i wspierał ich pracę. W rezultacie jego panowanie był okresem pomyślności i sprawiedliwości - w odróżnieniu od panowania jego z kolei syna, Swena Widłobrodego, który chrześcijaństwo odrzucił, za co spotkała go kara Boska ${ }^{58}$. W dalszej narracji Kościół i biskupi są obecni, ale raczej jako nowi aktorzy na politycznej scenie.

Podobnie jak u naszego Długosza, opowieść o najstarszych dziejach Danii poprzedza opis pogańskiej religii dawnych Skandynawów, czyli ich wersji mitologii germańskiej. Mitologia ta, w tym bogowie i boginie, jest dla autora skandynawskim odpowiednikiem mitologii klasycznej. Powielając informacje Saksona, który z kolei czerpał swą wiedzę z kroniki Adama z Bremy, autor charakteryzował panteon bóstw,

${ }^{54}$ H. I 1 s ø e, Arild Huitfeldts, s. 24.

${ }^{55}$ H. I $1 \mathrm{~s} ø$ e, En redegørelse, s. 48.

${ }^{56}$ DRK I, s. 294. Np. Bóg pokarał Swena Widłobrodego za odstąpienie od chrześcijaństwa, (DRK I, s. 55: „Lecz zasłużona kara za nasze grzechy nie była jeszcze pełna, toteż gniew Boży, zemsta i kara spadły na to królestwo, jak o tym następnie będzie mowa” - „Men vore Synders fortiente Straff vaar icke dermed fuldkommen oc bedret: Guds Vrede Heffn oc Straff paahengede dette Riget, som fremdeellis skal røris"; zob. też s. 413).

${ }^{57}$ DRK I, s. 554.

58 DRK I, s. 45, 49: „Siden drog Keyser Henrich med hans Krigsmact ind imod Danmarck Aar 934 - - . Deraff bleff Kong Gorm saa forfærdet at hand strax loffvet at giøre hvad hand vilde: oc tilstedde Christendommen i sit Rige". 
ich atrybuty i „kompetencje”, opisywał różne ceremonie, rytuały, nie omieszkując, jako jeden z pierwszych, zaprezentować także runicznego alfabetu ${ }^{59}$.

Umieszczając ten materiał, historyk ukazywał bogactwo kultury dawnych Skandynawów, jej równą pozycję z dziedzictwem antyku, choć zrezygnował z komentarzy, które w pracach renesansowych historyków o nacjonalistycznym nastawieniu były częste. Zakończył natomiast krótko: resztę pominę, odeszliśmy bowiem, dzięki Bogu, od tych błędów ${ }^{60}$. Jednak o jego stosunku do tych spraw świadczyć może też zastosowanie czasem przy opisie pierwszej osoby liczby mnogiej - my, nasza religia, nasze obyczaje. Nasuwają się tu skojarzenia z kroniką Marcina i Joachima Bielskich, gdzie występował podobny sposób pisania per „nasi” o dawnych Polakach. Tendencja patriotyczna jest wszakże u Huitfeldta zaznaczona raczej dyskretnie (inaczej niż u Vedla, który wielokrotnie wspominał, jak wielkie czyny były udziałem duńskich przodków i jak bardzo należy z nich być dumnym, czemu nie powinna przeszkadzać ich pogańska religia ${ }^{61}$ ). Autor Kroniki w ślad za Saksonem podkreślał, że cesarz rzymski nie ma żadnych praw zwierzchnich do Danii, bowiem król jest w pełni suwerenny ${ }^{62}$. Dawne dzieje były wypełnione zwycięskimi wojnami, a Danię autor często określał mianem potężnego królestwa. Ale jednocześnie potrafił zachować dystans: wspominając o wielkich sukcesach w wojnach z Anglikami w XI w., komentował lekko ironicznie: Anglicy mają pecha, ilekroć dochodzi do konfliktu z Duńczykami, zawsze ma miejsce zdrada w ich szeregach i Duńczycy zwyciężają ${ }^{63}$. Bywał też pełen krytycyzmu, kiedy zwycięskie wojny i wyprawy pokazywał jako źródło okrucieństw i zniszczeń: „Tego roku [1191] wyprawili się Duńczycy znów na kraj Wendów, jak to często czynili, niszcząc i paląc kraj oraz plony"64. Wojny z sąsiadami niekoniecznie były sprawiedliwe: kiedy dwaj królowie, norweski Olaf (Haraldson) i szwedzki Oluf (Skotkonung), uwolnili się spod władzy Danii, zaczęły się długotrwałe wojny z królem Kanutem (Wielkim), „,bowiem Duńczycy walczyli o władzę, a tamci o swoją wolność" 65 .

Huitfeldt okazywał obiektywizm, gdy chodzi o stosunki ze Szwedami w czasach sobie współczesnych ${ }^{66}$. W jego ujęciu unia między Danią i Norwegią a Szwecją miała na celu zachowanie pokoju i przyjaźni między narodami Północy, o jej w pełni legalnym charakterze świadczył zaś fakt, że została przyjęta za zgodą poddanych. Zatem wojny, jakie prowadzili Chrystian I i Hans, nie wynikały z żądzy zysku i z chciwości, ale były wojnami sprawiedliwymi, w celu przywrócenia legalnego status quo. Chodziło też o to, by pomóc Szwedom przeciwstawić się obcej sile

${ }^{59}$ DRK I, s. 2-3. O wczesnych badaniach nad runami w Skandynawii zob. K. S ze 1 a g ow ska, Scholars and the Magical World of Runes. The Beginnings of the Scientific Approach to Runes in 17th Century Scandinavia, Studia Historyczne 56, 2013, nr 3, s. 387-400.

${ }^{60}$ DRK I, s. 2.

${ }^{61}$ A.S. Ve de 1, Om Den Danske Krønicke at bescriffue, w: Humanister i Jylland, red. E. Munksgaard, København 1959, s. 131,

${ }^{62}$ DRK I, s. 145.

${ }^{63}$ DRK I, s. 58.

64 Tamże, s. 155: „Dette Aar [1191] foer de Danske atter i Læding til Lante Wenden, som de ofte giorde oc skende oc brende Landet oc Jordens Afgrøde".

${ }_{65}$ Tamże, s. 70: „De Danske kempedis for Regimentet, de andre for deris Frihed”.

${ }^{66}$ H. I 1 s ø e, Historisk censur, s. 49, określił to dowcipnie: ,produńska fairness”. 
(autor miał na myśli Albrechta Meklemburskiego). Huitfeldt zauważał jednak, że Szwedzi uważali unię za korzystną przede wszystkim dla Danii, król w ich oczach to przede wszystkim król Danii, urzędnicy duńscy, więc „Duńczycy byli panami, a oni niewolnikami i sługami, co im nakazano, musieli wykonywać” (,saa at de Danske vaare Herrer, de Træl oc Tienere, huad her befaledis, der effter skulde de dennem rette"). Autor przyznawał, że różni duńscy władcy mają na sumieniu przewiny wobec narodu szwedzkiego - dotyczyło to np. Eryka Pomorskiego ${ }^{67}$. Poza tym Szwedzi przyzwyczaili się do posiadania własnego króla. Nie zawsze, wzdychał historyk, sprawiedliwa wojna jest zwycięska, bowiem klęska może być karą Bożą za inne grzechy. Wszelkie szanse na poprawę stosunków i utrzymanie unii pogrzebały zbrodnie Chrystiana II. W ten sposób unia, której celem była zgoda i współpraca, stała się źródłem wiecznych podziałów, sporów i wojen, bowiem kolejni królowie duńscy, od Eryka Pomorskiego poczynając, próbowali zwiększyć swoją władzę nad Szwecją i wprowadzić w życie postanowienia unii, aż do pokoju szczecińskiego, w którym uznano związek za rozwiązany, a każde państwo za niezależne ${ }^{68}$. Huitfeldt miał zatem świadomość, że unia w dużej mierze była elementem ekspansywnej polityki Danii, a Duńczycy ponoszą przynajmniej częściową odpowiedzialność za jej upadek. Ostrzegał młodego króla, że z konfliktu z sąsiadami nic dobrego nie wyjdzie ${ }^{69}$. Doceniając umiarkowanie historyka, nie należy zapominać, że w traktacie szczecińskim (1570) rządy duński i szwedzki wpisały zakaz publikowania w czasach pokoju wzajemnych oszczerstw. Huitfeldt jako mąż stanu dobrze rozumiał, jak takie treści mogą być szkodliwe. Nie zmienia to faktu, że takie podejście nie wszystkim musiało się podobać. A. Vedel w roboczych notatkach z lektury Kroniki zarzucał Huitfeldtowi, że nadmiernie faworyzuje szwedzki punkt widzenia, nie realizuje zatem „patriotycznego" obowiązku dziejopisa ${ }^{70}$.

W wizji dziejów narodowych Huitfeldta można dostrzec szlachecki punkt widzenia. Przejawia się występowaniem następujących elementów. Jednym jest podkreślanie, że królestwo duńskie ma charakter elekcyjny, a jednocześnie rozciąganie tej cechy ustrojowej na całe dzieje Danii. Drugi zaś pojawia się w kontekście oceny władców: jednym z głównych kryteriów staje się to, w jakim stopniu król szanował przywileje szlachty, jej szczególne miejsce i prerogatywy. Im bliżej współczesności Huitfeldta, tym taka konstrukcja oceny staje się wyraźniejsza. Nieodzowną częścią tego rozumowania jest uznanie, że szlachtę, jej interesy, dążenia i poglądy reprezentuje Rada Królestwa, więc wyznacznikiem oceny króla stają się jego relacje z tą instytucją, czyli faktycznie z magnaterią. Trzecim elementem stają się formułowane przez historyka oceny szlachty - jej polityki i postępowania.

Wielokrotnie, zwłaszcza przy nowszych dziejach, Huitfeldt podkreślał, że Dania jest królestwem elekcyjnym (wolnym królestwem elekcyjnym) ${ }^{71}$. Zasada obioru króla

${ }^{67}$ DRK I, s. 769, 778, 787.

${ }^{68}$ DRK II, Kong Hans Krønicke, niepaginowana dedykacja.

${ }^{69}$ H. I 1 s ø e, En redegørelse, s. 39, zwrócił uwagę, że myśli te, zawarte w dedykacji do tomu o królu Hansie, ukazały się drukiem w 1599 r., kiedy polityczne elity znały już ekspansjonistyczne plany wojenne Chrystiana IV.

${ }^{70}$ H. I 1 s ø e, Arild Huitfeldts Krønike, s. 32.

71 „Valrige”, „frit Valrige” - DRK I, s. 105, 441, 561, 818. 
została wspomniana po raz pierwszy w chwili objęcia tronu przez Kanuta Wielkiego (XI w.) - mowa tam o żeglarzach i wojownikach („Danske Skibsflode, Krigsfolcket”) ${ }^{72}$. Przy kolejnych władcach tej epoki pojawiła się adnotacja, że wybrani zostali ,za zgodą wszystkich” („med alles Ja oc samtycke”), względnie „,za zgodą stanów”73. Pojawił się też „Herredag”, na którym podejmowane były decyzje. Używane przez historyka formuły nie są jednoznaczne, może np. pojawić się sformułowanie o uczestnikach zjazdu: „gmin, cała szlachta i rycerstwo"74, może być tylko szlachta ${ }^{75}$, mamy też dokładniej (1320): „pełnomocnicy stanów Królestwa, szlachty, miast i gminu”76. W dedykacjach dla Chrystiana IV, zwłaszcza w części poświęconej Oldenburgom, elekcyjność tronu nie tylko jest podkreślana, ale historyk próbuje ją też wyjaśnić: „Stany tego królestwa złożyły hołd, zaprzysięgły [wierność] i wybrały Wasz Majestat wedle prawa, jakiego przestrzegali Wasi znamienici rodzice, bowiem jest [to] Królestwo nie dziedziczne, ale wolne [i] elekcyjne. Dawniej żadne królestwo nie było dziedziczne, ani władza nie była dziedziczna, ale ludzie mianowali i wybierali tego, który był najcnotliwszy, najrozumniejszy i najzdolniejszy. Przy tym obyczaju, wskutek długotrwałego stosowania i przyzwyczajenia, zostało spośród [państw] chrześcijańskich to Królestwo [tzn. Dania], Polska i wiele innych"77.

Jest więc elekcyjność tronu efektem przywiązania do prastarych rozwiązań prawnych, zaś dziedziczność - skutkiem przemian historycznych. Że elekcyjność autor uważał za lepszą, wynika z różnych uwag, np. komentarza przy informacji o wprowadzeniu w Szwecji przez Gustawa Erikssona dziedziczności tronu (ta decyzja z 1543 r. połączona była z wydzieleniem dzielnic dla synów króla): „Lecz czy to będzie pożytkiem dla kraju, że podzieli się go na małe części dla królewskich dzieci i odda pod władzę różnych osób, przyszłość pokaże. My tu w Danii jesteśmy już mądrzy po szkodzie"78.

Podkreślanie fundamentalnej roli elekcyjności tronu nie przeszkadza autorowi uznawać znaczenia pokrewieństwa, czyli wywodzenia się z królewskiego rodu. Dla dawniejszych czasów ród ten właściwie nie ma imienia, tzn. nie ma jednej nazwanej imieniem dynastii, która pełniłaby rolę „kośćca” narodowej historii i państwowości. Mowa jest ogólnie o rodzie królewskim („kongelige Stamme”, „Slect”), czemu

72 Tamże, s. 63.

73 Tamże, s. 79, 90, 198.

74 Tamże, s. 171: „den Menige Mand, gantske Adel og Ridderskaff”.

75 Tamże, s. 183.

76 Tamże, s. 411: „meenige Rigens Stender, Adelen, Kiøbstædernes oc Meenighedernis Fuldmectige".

77 Tamże II, niepaginowana dedykacja w opisie panowania Chrystiana III: „haffuer disse Rigers Stender samptlig hyldit, sorit oc udvald Eders Maj. oc derhen seet, oc til det lofflige Regiment, som Eders fremfarne Forældre haffue ført, huilcke Kongedomme icke er nogle Arfferige men fri Valriger. Aff første da vaare ingen Kongeriger eller Herschaff Arfflige, som nu en Part ere, men da tilskickede oc udvalde Folckit den, som dydeligste, Forstandigst oc Beqvemmeligst vaar. Ved same Skick er dette Rige, Polen oc nogle fleere udi Christendommen aff langsommelig Brug oc Indskickelse bleffne".

78 DRK II, s. 1532: „Men om saadant skal vaere gafnligt, at it Rige byttis udi mange Parter under en Kongis Børn oc under it adskillige Herskaff, det giffver fremtid tilkiende. Vi ere det her udi Danmark tilforn icke uden Skade vijs vorden". 
towarzyszy określenie pokrewieństwa. Można wszelako wyczuć pewien dystans: autor był świadom tego, jakie to było dla ludzi istotne, choć tego przekonania nie podzielał: ,jeden zwał się Harrild Streng, urodzony w naszym duńskim królewskim rodzie, krewny zabitego w Roskilde króla Kanuta, ani wymowny, ani potężny, żadnymi szczególnymi cnotami nie obdarzony, tylko dlatego, że zrodził się z krwi królewskiej - jemu dali koronę"79. Czasem wzgląd ten łączył się z zasługami, jak w przypadku króla Waldemara (I), który otrzymał koronę tytułem swego królewskiego rodowodu, ale też dla swoich wojennych sukcesów ${ }^{80}$. Także oddanie władzy królowej Małgorzacie, mimo iż była kobietą, wynikało z jej pochodzenia z królewskiego rodu oraz z przymiotów charakteru ${ }^{81}$. Jasno wyraża pogląd autora komentarz przy okazji opisu debaty nad sukcesją po Eryku Pomorskim: „Rada Królestwa nie chciała pozwolić, by ktoś ją zmuszał do przyjęcia jakiegoś króla, ani z powodu [woli] Eryka, ani przez wzgląd na dziedziczenie, powołując się na fundamentalne prawa tego królestwa, które jest wolnym królestwem elekcyjnym i Rada nie musi oddawać korony temu, kto jest najbliższym krewnym, czy to po mieczu, czy po kądzieli, ale temu, komu chce" $"$.

Ostatecznie w opisie procedury wyboru króla różne elementy układają się w harmonijną całość. Huitfeldt zarysował ją, tworząc także pewien schemat opisu, w chwili omawiania objęcia tronu przez Chrystiana I, czyli nową dynastię - wszyscy kolejni królowie będą odtąd precyzyjnie identyfikowani jako pochodzący z rodu Oldenburgów. I tak odnotowane zostało pochodzenie „ze starego królewskiego rodu” (,,af det gamle Kongelige Slect"), w domyśle duńskiego, jako że Chrystian I był wnukiem po kądzieli Waldemara IV Odnowiciela. Następnie przedstawiona zostaje kapitulacja, której treść autor przytacza, zaprzysiężona przez wszystkie zainteresowane strony: szlachtę, lud i króla. Opis procedury wieńczy ceremonia koronacyjna z udziałem arcybiskupa, w trakcie której król ponownie zapewnia stany królestwa o gotowości przestrzegania ich przywilejów i wolności ${ }^{83}$. Czynnik religijny jest tu mało istotny, bowiem, choć udział Kościoła został zaznaczony, autor nie podkreślał metafizycznego charakteru władzy królewskiej, nie odwoływał się do czynników nadprzyrodzonych przy definicjach i opisach systemu ustrojowego.

Kolejne zagadnienie to pytanie, czy dla Huitfeldta szlachta pozostawała, na doczesnej płaszczyźnie, głównym motorem i siłą sprawczą dziejów. Choć wydawałoby się, że przyjęcie szlacheckiej perspektywy powinno wskazywać takie ujęcie, to przy bliższym przyjrzeniu się, sprawa nie jest oczywista. Podobnie z poglądem na charakter i genezę tej grupy. Po pierwsze, uderza nowoczesna interpretacja genezy

79 Tamże I, s. 140: „en heed Harrild Streng, føde aff voris Danske Kongelige Slect, af Kong Knuds Stamme, som bleff slagen i Roskilde, hverken talende eller mectig, heller med nogen lofflige Dyder beguaffet, uden alleniste at hand var fød aff Kongelige Blod: hannem gaff de Konge Naffn".

80 Tamże, s. 171.

81 Tamże, s. 573.

82 Tamże, s. 818: „Saa vilde dog Danmarckis Raad icke lade tvinge dem nogen Konge paa, enten for Kong Erichs skyld, eller paa Arffs vegne, brugendis der udi dette Rigis fundamentale Low, som er it frit Valrige, icke tilbunden at tage den som næst er i Byrd, eller paa Sverdsiden, men huem som deris gode villie tager".

${ }^{83}$ Tamże, s. 843-848; w odniesieniu do wyboru króla Hansa: tamże II, s. 962-976. 
szlachty. Huitfeldt umieścił w części omawiającej średniowiecze niewielki fragment wyjaśniający pochodzenie szlachty, ujmując rzecz, by użyć współczesnego słowa, komparatystycznie, czyli wskazując na podobieństwa i różnice między sytuacją w Danii i krajach niemieckich. Historyk ukazał w istocie proces historyczny, co samo w sobie jest raczej rzadkie w epoce. Tak więc w Niemczech (Tydskland) za czasów cesarza Ludwika w X w. tytuły hrabiów i margrabiów były tylko nazwami urzędów, a pełniący je ludzie wywodzili się z wolnych wojowników. Otrzymywali ziemię od cesarza, ale nie dziedziczną i wykonywali różne obowiązki administracyjne i wojskowe. Cesarz Otton III wprowadził zmianę, a „hrabiowie stali się dziedziczni i zostali wyniesieni ponad wolnych ludzi: rycerze stali się szlachtą rodową" ${ }^{84}$. W Danii natomiast, kontynuował historyk, szlachta powstała w czasach pierwszych Waldemarów ${ }^{85}$. Przywołał ogłoszone w 1241 r. Prawo jutlandzkie (Jyske Lov), w którym pojęcie „Herremand” - odpowiednik szlachcica - pojawiło się dopiero w księdze 3, przy regulacjach dotyczących pospolitego ruszenia: był to zapis, że szlachcic - z tytułu poświęcania życia w obronie króla i państwa - miał prawo zakupu gospodarstwa (którego nadanie wiązało się z wypełnianiem obowiązków naczelnika). W owym czasie, pisał dalej Huitfeldt, szlachcice podlegali temu samemu prawu, co inni i dopiero, kiedy nabyli gospodarstwa naczelników, stali się wolni (od zobowiązań), podobnie jak szlachta w Szwecji i Norwegii. Z czasem nadane im ziemie stały się dziedziczne. „W dawnych czasach wielu było pasowanych na rycerzy za dzielne uczynki; ale ten stan i wolności przynależały tylko tej [konkretnej] osobie, nie przechodziły na potomków, dopóki u nas, w ślad na niemieckim zwyczajem, nie zaczęła się zmiana oraz nowe obyczaje wojenne, tak że szlachta stała się rodowa"86.

Jest więc szlachectwo rezultatem historycznego rozwoju, przeobrażeń związanych z decyzjami władców, ale też zmianami w armii. Sprawę tę reguluje prawo i nie ma tu nic szczególnie wyjątkowego - Huitfeldt przy okazji przywołał zapis prawa, które nadawało pewną wolność od zobowiązań także chłopom posiadającym ziemięę7, i zwracał uwagę, że zapis ten jest taki sam w przywilejach szlacheckich jego czasów. Nie ma tu żadnego odwołania do jakiejkolwiek mitologicznej genealogii czy legendarnych początków. Omawiając kwestię pochodzenia szlachty, Huitfeldt wykazał się nowoczesnym podejściem do materii historycznej. Był świadom historycznej zmienności, reprezentował zatem ówczesny historyzm oraz wykonał dojrzały metodologiczny zabieg, konfrontując źródło opisowe (czyli średniowieczne kroniki) z tekstem normatywnym (czyli prawem), będącym przecież cząstką rzeczywistości dziejowej.

${ }^{84}$ Tamże I, s. 147: „The Greffue er bleffne Arffherrer oc ere opstigde offuer fri Folck: Riddermænds Mænd ere bleffne slet oc aldeles Arffadel".

${ }^{85}$ Waldemar I (Wielki) panował w 1. 1154-1182, zaś jego syn Waldemar II (Zwycięski) w 1. 1202-1241.

${ }^{86}$ Tamże: „Udi fordumme Dage bleff der vel mange for deris Mandoms Gierninger slagne til Riddere: Men den Stand oc Frihed vaar icke uden paa Person allene, icke paa deris Efterkommere før nu, at vi efter den Skick som udi Tydskland vaar begynt her oc begynte der paa en Forandring oc ny Krigsbrug saa at Adelstanden er blefuen arfuelig".

${ }_{87}$ Tamże, s. 147: Recepimus eum in hominem nostrum, demittendo eum et liberos ipsius quitrum et liberum, ab omni expeditione, quod Stud et Inna dicitur. 
Nie ma w dziele Huitfeldta koncepcji szlachty jako grupy, która - obok króla, wbrew niemu lub wraz z nim - wyłącznie kształtuje dzieje. Praktycznie na każdym ich etapie swój udział w wydarzeniach mają wszystkie grupy społeczne. W dawnych czasach wpływ mieli przede wszystkim „wojownicy” (Krigsfolck) ${ }^{88}$. Udział chłopów/ludu w dziejach polegał na ich buntach (czasem zasadnych, bowiem nakładano na nich niesprawiedliwe ciężary) lub dążeniu do zemsty, a bywali też podburzani

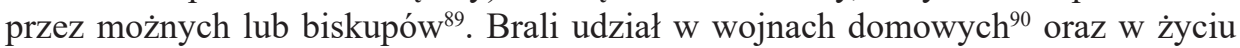
politycznym - nie tylko uczestniczyli w wyborze króla, ale i też jego w działaniach prawodawczych. Huitfeldt pisał, jak oba zbiory praw, przyjęte przez króla Waldemara Zwycięskiego, zostały zaakceptowane przez szlachtę i lud'19. Podobnie pokazywał, jak poddani zatwierdzali różne umowy (także międzynarodowe) i decyzje ${ }^{92}$. Brali także udział w hołdach nowo wybranym monarchom: w ceremonii króla Hansa (1481) wzięły udział „stany Królestwa: prałaci, szlachta, mieszczanie i chłopi"93. Rola chłopów widoczna była także w Szwecji, bo to oni np. zbuntowali się przeciw niemieckim i duńskim urzędnikom, którzy za rządów Eryka Pomorskiego dręczyli ich ciężarami i łamali prawo. Takie bezprawie - a Huitfeldt przyznawał, że miało miejsce za rządów zarówno Albrechta Meklemburskiego, jak i królowej Małgorzaty oraz Eryka Pomorskiego - było przyczyną, że „chłopi zburzyli tyle zamków"94.

Szlachta jednak pozostawała główną, obok króla, który zawsze ukazany jest jako pierwszy aktor i sprawca, siłą polityczną w dziejach. Jej najważniejszą kompetencją polityczną był udział w wyborze władcy, jak o tym była już mowa, podobnie jak w tworzeniu praw. Formalną podstawą przywilejów były kapitulacje - historyk całkowicie zgodnie z historyczną rzeczywistością informował o pierwszej, podpisanej w 1282 r. przez króla Eryka (Menveda), wiążąc ją ze współczesnymi sobie (,taka, jaką dziś mamy” - „som nu tilstede er”) ${ }^{95}$. Kapitulację opracowywało zgromadzenie „powszechnego Danehof” (,,almindelige Danehof”).

Ukazanie dużej roli szlachty wyraża się nie tylko podkreślaniem znaczenia jej działań (nie zawsze pochwalanych), ale wprowadzaniem instytucjonalnych form jej wpływu, takich jak Herredag, Danehof (czasem zamiennie pojawia się określenie: Parlemente ${ }^{96}$ ) czy wreszcie Rada Królestwa (Rigets Raad), której obecność Huitfeldt

${ }_{88}$ Tamże, s. 145: „Men[s] dette skeede [1186 r.], beklager sig det danske Krigsfolck som under Konning Waldemar vaar brugt udi adskillige Krig, at deris Mact fortæredis uden de blefue brugte oc øffude udi Krig. Deerfore blef et Thog bevilget imod Estland".

${ }^{89}$ Tamże, s. 139, 243, 284, 367.

90 Tamże, s. 28: „Her bleff udi Riget saadant it Blodbad [858 r.] baade aff Almuens Folck oc Herrerne at ingen igien bleff lefvendis aff det gantske Kongelige Slecte, kun it Barn, som oc heed Erich".

${ }_{91}$ Tamże, s. 173, 206.

${ }_{92}$ Tamże, s. 79.

${ }_{93}$ Tamże II, s. 962: „Rigens Stænder, Prælater, Adel, Kiøbstædmænd oc Bønder”.

${ }^{94}$ Tamże I, s. 769, 778 („,Store Offervold oc Uret som skeede i Landet [Szwecja] oc i Lang til haffde baade i Konning Albrets, Dronning Margrete oc denne Kong Erich tid, haffue været rette Aarsage, huorfore Bønderne haffue brudet saa mange Slot neder”).

95 Tamże, s. 284.

96 Tamże, s. 421. 
dostrzegł już w XI w. ${ }^{97}$ Tak opisał grupę możnych, którzy zebrali się na wezwanie króla Kanuta (Wielkiego): biskupi, książęta, hrabiowie i najznaczniejsi ze szlachty, umieszczając na marginesie notkę: ,zbiera się rada” („Raadet forsamlis”) ${ }^{98}$. Nie ma zresztą tu terminologicznej konsekwencji, bowiem zdarza się, że pojęcia Rada i Herredag występują zamiennie, nie ma też czytelnego rozgraniczenia obu instytucji od Danehofu - co w istocie odzwierciedlało stan faktyczny ${ }^{99}$. Tak więc Herredag gromadzi elity: są to synowie królewscy, biskupi, Rada Królestwa i „najznamienitsza szlachta” (,ypperste Adel”) ${ }^{100}$, ale czasem też gmin (,menige Stender”). Dla dawniejszej historii Huitfeldt stosował ogólniejsze formuły: bezpośrednio z królem współpracują, podejmując decyzje lub zatwierdzając je, „najstarsi i najlepsi w królestwie” („de aeldste oc beste i Riget”) ${ }^{101}$, „najznakomitszy i najznaczniejsi” (,ypperste oc fornemste") ${ }^{102}$. W ten sposób, intuicyjnie zapewne, Huitfeldt złagodził występujący w tych informacjach ahistoryzm: Rada pojawia się w zamierzchłej przeszłości, ale nie jest to ta sama Rada, z jaką mamy do czynienia w nowszych czasach. W tym przypadku dominuje forma Rada Królestwa - w częściach poświęconych władcom piętnasto- i szesnastowiecznym nie ma już wątpliwości, że przy królu funkcjonuje organ mający wiele do powiedzenia. Ta pozycja ujawnia się w opisie różnych wydarzeń, czasem drobnych. I tak, wedle Huitfeldta, krytyczny stosunek księcia Chrystiana (to późniejszy Chrystian II) wobec pewnych podjętych uprzednio decyzji nie miał znaczenia, recesy zostały bowiem opieczętowane przez Radę, a więc nabrały mocy prawnej ${ }^{103}$. Uwolniona ze szwedzkiej niewoli królowa Krystyna (małżonka króla Hansa) otrzymała od szwedzkiej Rady „świadectwo moralności”, czyli pismo, zaświadczające, że „w niewoli dobrze się prowadziła”104.

W większości przypadków rola i możliwości Rady wynikają wprost z opisu przebiegu wydarzeń, w którym ta instytucja jest głównym (faktycznie jedynym) podmiotem działającym. Przede wszystkim widać to w chwili śmierci króla, kiedy po debatach podjęta zostaje decyzja o następcy - zwłaszcza, gdy zmarły król nie zostawił męskiego potomka, albo z jakichś względów ten potomek budził wątpliwości, jak po śmierci Waldemara Odnowiciela lub po wypędzeniu Eryka Pomorskiego. W sytuacji stabilnej Rada przeprowadzała wszystkie nieodzowne procedury. W opisie wojen ze Szwecją za króla Chrystiana I i Hansa to duńska Rada jest pokazana jako partner w rozmowach ze szwedzkimi możnymi. O tym, że Rada stawała się niezależnym podmiotem w polityce, świadczy także fakt, że Huitfeldt w pewnym momencie zaczął podawać informacje „osobowe”, wymieniając z nazwiska uczestników różnych zdarzeń, obsadę personalną urzędów, w tym skład Rady - pierwsze takie informacje pojawiły się sporadycznie przy opisie wydarzeń z XIV w. ${ }^{105}$, zaś

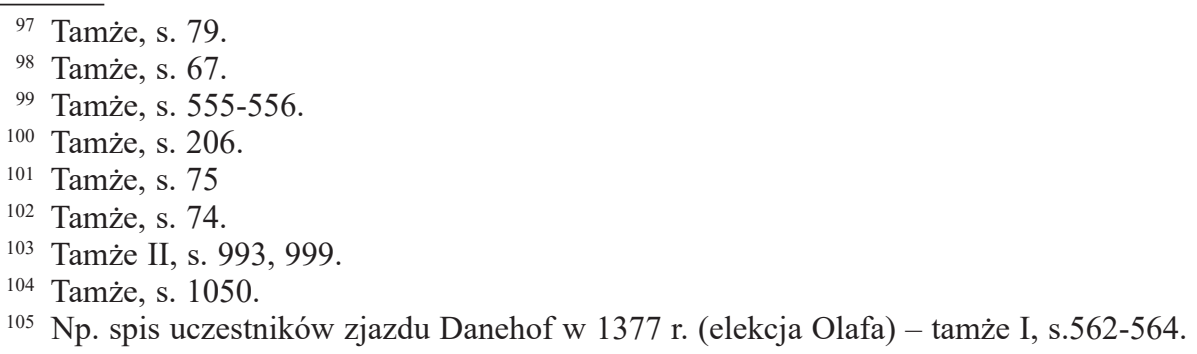


regularnie już od chwili objęcia władzy przez Oldenburgów $(1450)^{106}$. W tych częściach historyk zaczął skrupulatnie wymieniać nazwiska możnych, którzy podpisali się pod przytaczanymi dokumentami i przyłożyli swoją pieczęć. Podanie nazwisk dygnitarzy (wraz z urzędem) staje się informacją o wykrystalizowaniu się w Danii rządów szlachty. Tym bardziej, że w tym czasie poszczególni wysocy urzędnicy, także duchowni, ukazywani byli jako bohaterowie wydarzeń. Faktografia stawała się coraz bardziej szczegółowa, a to oznaczało, że wymagała podania konkretnych uczestników. Co bardziej znamienici ludzie zostali uhonorowani informacją o ich śmierci ${ }^{107}$. Ochmistrza koronnego Mogensa Gøye (zm. 1544) pożegnał historyk komentarzem: „Był jednym z najpotężniejszych rycerzy, którego majątek ziemski nie miał sobie równych od stuleci ani u nas, ani w Niemczech"108.

Rola Rady została uwypuklona przez autora we fragmentach „teoretycznych”, czyli w dedykacjach dla Chrystiana IV. Już w pierwszej z nich, poprzedzającej opis panowania Chrystiana III (wydany w 1595 r.), która dodajmy, przypomina politologiczny traktat, Huitfeldt starał się wyjaśnić zasady systemu politycznego i miejsce w nim Rady. Dobry władca, pisał, powinien odznaczać się licznymi cnotami, ale przecież żaden człowiek nie jest doskonały, a więc: „Powinien pan i władca zebrać przy sobie mądrych i znamienitych ludzi, których rad będzie słuchał, tak że co uzna za stosowne, dzięki ich dobrym radom, zostanie wprowadzone i ustanowione, a rządy będzie dzielić z innymi” ${ }^{109}$. Gdzie indziej stwierdzał: „u nas Rada ma moc i władzę mianowania króla, bowiem to królestwo jest wolnym królestwem elekcyjnym i nie mamy żadnego obcego władcy nad sobą"110. Historyk wyraźnie rozdzielał państwo od króla. Uprawnienia Rady wynikają też z tego, że jest to organ państwowy, nie królewski - urzędnicy są bowiem zobowiązani do dbałości o dobro państwa. W Danii ochmistrz, kanclerz, marszałek, radcy, a w Polsce wojewoda, kasztelan - przysięgają nie tylko wierność królowi, ale też państwu (,,men oc Riget at skulde vide diss Beste”) ${ }^{111}$.

Uznaniu ważnej roli szlachty w dziejach towarzyszyła jednak często krytyka jej działań. Najostrzejsza jest wtedy, gdy historyk zarzucał przodkom walki wewnętrzne. Surowo oceniał działania hrabiów i książąt (ale też popierającą ich szlachtę) po śmierci Waldemara II: „i po jego śmierci zaczęli ludzie kłócić się między sobą, prowadzić wojny, szkodzić sobie wzajemnie, [tak] że stali się pośmiewiskiem dla sąsiednich krajów: ziemie, które ojcowie zdobyli mieczem i zwycięstwami, odpadły

${ }^{106}$ Pod 1381 wymienił 22 rodziny szlacheckie w Norwegii, a pod 1500 r. umieścił listę nazwisk szlachciców poległych w bitwie (tamże I, s. 566, II, 1034); zob. też tamże II, s. 962, 992-993, 1395.

107 Tamże, s. 1524, 1538, 1549, 1547.

108 Tamże, s. 1535: „Hand vaar en aff de mectigste oc rigeste Riddere paa Jordegods, hues lige icke haffuer værit her eller i Tydskland udi nogle hundrede Aar".

109 Tamże, niepaginowana dedykacja w opisie panowania Chrystiana III: „Da skal en Første oc Herre samle til sig forstandige, vise oc fornemme Folck, deris Raad skal hand bruge, saa at huad udi hannem fattis, kand ved deris gode Raad blifue erstadit oc opret oc formiske Regimentit med fleere".

${ }_{110}$ Tamże, niepaginowana dedykacja w opisie panowania Fryderyka I: „,hos Rigens Raad er Mac toc Voldt at neffne en Herre oc Konge til dette fri Val-Rige, oc vi icke kiende nogen anden udvortis Herre ofuer os".

111 Tamże, s. 1211. 
od Korony, co stało się z naszą stratą, jak to dzisiaj widzimy. Do tego doprowadzili naczelnicy swymi wewnętrznymi wojnami" ${ }^{112}$. Ale rzecz nie kończy się na zastosowaniu mądrości ludowej, że ,zgoda buduje, a niezgoda rujnuje”. Huitfeldt zwracał uwagę na uwarunkowania geopolityczne: „Ten kraj [tzn. Dania], który przecież nie jest duży, nie znosi dzielenia na mniejsze części”"113. Sumując: „Z jego [Eryka Plogpenninga historii] widzimy i możemy doświadczyć, co wewnętrzne rozbicie i spory czynią królestwu. A także to, że nigdy nie przyniosło korzyści, że Królestwo Duńskie dzielono na części, co zawsze sprowadzało partyjność i wielkie podziały"114. Historyk zwracał też uwagę, że wojny wewnętrzne dlatego są tak niebezpieczne, bo stają się okazją dla sąsiadów, by wtrącać się w sprawy kraju ${ }^{115}$.

Z oceną szlachty bezpośrednio łączy się ujęcie w Kronice prawa do oporu, a pytanie, czy poddani mają prawo obalić władcę, a jeśli tak, to w jakiej sytuacji i pod jakimi warunkami, stanowi istotny element rozważań nad obrazem władcy niegodnego i idealnego. Bezpośrednio ukazują one preferencje polityczne, dając zarazem charakterystykę ustroju państwa. Refleksja nad ideałem władcy była w renesansie bardzo popularna. Oddawały się jej tak potężne umysły, jak Erazm z Rotterdamu (Institutio Principis Christiani, 1516, tłum. duńskie Poula Helgesena 1534), Macchiavelli czy Francesco Guicardini, a z mniej sławnych - Philippe de Commines. Kwestia prawa do oporu łączyła się na ogół z analizowaniem istoty tyranii, z charakterystyką i definicją tyrana $^{116}$. Prawo oporu występowało już w średniowiecznych doktrynach politycznych, ale w XVI w., dobie wojen religijnych, motyw ten stał się szczególnie istotny. Często był poruszany w publicystyce hugenockiej, w piśmiennictwie monarchomachów. Huitfeldt korzystał z tak znanych i popularnych prac, jak Vindiciae contra tyrannos (1579) ${ }^{117}$, Teodora de Bèze (1519-1605) De iure magistratuum (1574) czy z odpisów szwedzkiej kroniki Olausa Petri ${ }^{118}$.

„Zły” król łączy podłość charakteru i różne niedobre skłonności z niewłaściwą polityką: nakładaniem nadmiernych ciężarów, łamaniem zobowiązań, odrzucaniem współpracy z Radą Królestwa i łamaniem prawa. Schemat był uniwersalny, bo Huitfeldt

112 Tamże I, s. 208: ,efter hans Død begyndte Landmaend indbyrdis at kifve, krige oc orlofue at fordefue huer andre, saa de bleff alle omliggendis Lande til Spot og Spee: de Lande som Forældre haffde vundet med Sverd oc seyer, komme fra Kronen oc bleff os meest imod til Skade, som vi dagligen finde. Det hafuer Høvitzmenden voldet med indbyrdis orloff”; podobnie s. 220, 225 .

113 Tamże, s. 209: „Serdelis taal ikke dette Rige, som icke er stort, at skiftis oc deelis udi mange Parter".

114 Tamże, s. 225: „Aff dennes Kongis [Eryk Plogpenning] haue vi at see oc forfare, hvad indbyrdis Riff oc Trætte formaar udi it Rige. Til med at det aldrig hafuer været gaffnligt at Danmarckis Rige er skifft oc deelt udi Parter, huilcket altid haffuer medført Parthi oc stor Tuedract".

115 Tamże II, s. 1552.

116 A. Z a krze w s k i, Prawo oporu w Wielkim Księstwie Litewskim od wieku XIV do XVIII, w: Król a prawo stanów do oporu, Kraków 2010, s. 28.

${ }_{117}$ Zdaniem S. Gr zy b o w s k i e g o, Prawo oporu - dylemat szekspirowski, w: Król a prawo stanów do oporu, s. 37, autorem tej pracy był Henri Estienne Młodszy (zm. 1598), francuski filolog, znawca greki, wydawca i humanista.

${ }_{118} \AA$ A. Hermans s o n, Karl IX, s. 307-315; H. I1 s ø e, En redegørelse, s. 3, 6-10, 17 , 29, 55-56, 66. 
zastosował go także w odniesieniu do szwedzkiego króla Magnusa Erikssona (XIV w.), którego potępia za sprzymierzenie się... z Danią ${ }^{119}$. Analogicznie, łamanie zasady indygenatu (w Szwecji) zawsze zasługuje na potępienie, nawet jeśli korzystają na tym rodacy autora (tzn. Duńczycy). W trzech przypadkach historyk rozbudował charakterystykę „złego” króla, jako że miało miejsce jego obalenie i wygnanie, czyli zastosowanie przez poddanych prawa do oporu. Idąc wedle kolejności napisania, czyli wbrew chronologii dziejów, byli to Chrystian II (XVI w.), Eryk Pomorski (XV w.) i Krzysztof II (XIV w.). Najbardziej rozbudowany jest fragment dotyczący Chrystiana. W tym przypadku argumentacja historyka dzieli się na dwa rodzaje: argumenty prawne, historyczne i religijne oraz opis zachowania, charakteru i uczynków króla. Tym pierwszym jest odwołanie się do zapisów kapitulacji, wsparte przywołaniem analogii z innych krajów, jak np. Maria Stuart wygnana ze Szkocji, Eryk szwedzki (XIV) zamknięty w dożywotnim więzieniu czy Henryk Walezy, który nie chciał mieszkać w Polsce, więc trzeba było zorganizować nowy wybór ${ }^{120}$. Autor wspomina też Niderlandy, które niedawno odłączyły się od Hiszpanii w obronie religii, ale też dla utrzymania przywilejów i wolności. Z bardziej odległej przeszłości wzięty był przykład Francji, gdzie stale zmieniały się dynastie, czy liczne przypadki z dziejów starożytnego Izraela, opisane w Starym Testamencie. Historyk wspomógł się argumentem religijnym: Bóg nakazuje słuchać władców, ale przecież wystąpienie przeciw władcy dokonuje się też z jego inspiracji - gdyby nie to, nigdy by się powiodło; to Bóg uznał, że tyrana trzeba ukarać121.

Zarzuty formułowane wobec Chrystiana II przedstawione zostały w takiej kolejności: Niesłychanym aktem tyranii była sztokholmska krwawa łaźnia, której dorównała dopiero Noc św. Bartłomieja; w Danii król pohańbił swą małżonkę, sprowadzając dziewkę Dyveke, z którą wiódł bezbożne życie, a jej matce, kobiecie z Holandii, o której mówiono, że rzuca czary, oddał władzę nad państwem duńskim; pogardzał Radą, szlachtą, prześladował ją, wypędził arcybiskupa Trondheim Eryka Valkendorffa, uwięził biskupów. „Posła króla polskiego kazał zabić przy Østre Strand, co jest niesłychane wśród chrześcijan. Ba! nawet między Turkami posłowi, który przybył, nie czyni się krzywdy"122. Zestawienie tyrana z uśmiercaniem posłów było zabiegiem typowym ${ }^{123}$.

W dalszym ciągu pretensji mamy: król wbrew woli Rady i bez jej zgody prowadził wojny z Lubeką i stryjem Fryderykiem, chciał nałożyć podatki na chłopów, szlacheckich poddanych, i żeby zmusić szlachtę, by na to się zgodziła, ściągnął niemieckich rycerzy (jeźdźców) i piechotę. Udawał ewangelika i oszukał wszystkich,

${ }_{119}$ DRK I, s. 531.

${ }^{120}$ Kontekst sugeruje, że Walezy też został wygnany, co nie jest ścisłe, uciekł bowiem sam. Takie ujęcie pochodzi prawdopodobnie z francuskich tekstów politycznej opozycji przeciw Walezjuszom (H. I1 s ø e, En redegørelse, s. 67).

121 DRK II, s. 1209-1210.

122 Tamże, niepaginowana dedykacja w opisie panowania Chrystiana II: „Kongens Sendedbud aff Polen lod hand omkomme udi den Østre Strand, som er uhørlig iblant Christen Folck. Ja end ey iblant Tyrcker et Sendebud som til hannem selff sendis skulde belegedis oc skadis".

${ }^{123}$ Znalazło się także w rozważaniach litewskiego magnata Mikołaja Radziwiłła Rudego z 1570 r. (A. Z a k r zew s k i, Prawo oporu, s. 29). 
także Marcina Lutra i uczonych z Wittenbergi. Wprowadził ich w błąd, bowiem: „tyle tylko wiedzieli, że był protestantem i został wygnany przez biskupów i szlachtę za to, że zajął się sprawami religii i bronił biednych przed możnymi" ${ }^{124}$. W tym zdaniu występują dwa wątki. Jeden dotyczy faktu, że Duńczyków za obalenie Chrystiana II skrytykował sam Luter, stojący na stanowisku nienaruszalności władzy królewskiej. Jego pismo w tej sprawie zostało w Danii zakazane, ale fakt był znany i wymagał wyjaśnienia $^{125}$. Druga sprawa to decyzje Chrystiana faworyzujące kosztem szlachty mieszczan i chłopów (taką antyszlachecką polityką król budował swoją alternatywną bazę polityczną i był to prawdopodobnie kluczowy powód wystąpienia przeciwko niemu). Chodzi tu przede wszystkim o reces z 1521 r., który nakazywał szlachcie sprzedawać plony w duńskich miastach. Tę sprawę Huitfeldt komentował jednoznacznie. Po pierwsze decyzja była ekonomicznie bezzasadna, bowiem mieszczanie duńscy byli za biedni, by móc kupować od szlachty i duchowieństwa zboże, po drugie była bezprawna, bowiem sprzeczna z przywilejami i wolnościami szlachty oraz z obyczajem (,,imod Adelens Privilegier, Friheder, gammel Brug oc Sedvane”), po trzecie wreszcie były to działania pozorne, bowiem król wszystko robił dla własnych korzyści, a jego główny motyw to nie dbałość o chłopów i mieszczan, ale chęć pognębienia szlachty oraz miast północnoniemieckich, a przy okazji nastawienie gminu i mieszczan przeciw szlachcie. „Tak więc oszukał wielu, [a] zyskał poparcie zwykłego człowieka, który nie znał go naprawdę" 126.

Historyk podsumował ocenę króla, tworząc jego czarną legendę, w takich słowach: „Zaprawdę, był panem i władcą bezbożnym, złym, grzesznym, tyrańskim, krwawym, a jego rządy były nie do zniesienia - - . Rządził bez praw i zasad, ani nie chciał się im podporządkować, choć dobry cesarz Teodozjusz mawiał, że źródłem władzy jego i wszystkich innych panujących jest prawo. I [dlatego] uważa się go za wielkiego monarchę, który jest ponad całym państwem i tym, co każdy człowiek posiada, z wyjątkiem prawa, zwyczaju, przywilejów i wolności. Były zatem przyczyny, że utracił [Chrystian] prawa do królestw Danii, Szwecji i Norwegii, a one prawnie wystąpiły przeciw jego gwałtom, tyranii i postarały się o inną zwierzchność: jedna część wzięła sobie Fryderyka księcia Holsztynu, druga - Gustawa Erikssona"127.

${ }^{124}$ DRK II, niepaginowana dedykacja w opisie panowania Chrystiana II: „huilcke icke viste andit, end han vaar Evangelisk oc vaar forjagit aff Bisperne oc Adelen for hand antog sig Religionen oc beskermede de Fattige imod de som mectig være".

${ }_{125}$ H. I $1 \mathrm{~s} ø$ e, En redegørelse, s. 53.

126 DRK II, s. 1172: „Deroffver missbrugte hand mange, fick Gunst oc Yndist aff den menige Mand, hannem icke ret kiende".

127 Tamże, niepaginowana dedykacja w opisie panowania Chrystiana II: „Hand haffuer værit en Herre oc Første uden al Guds Fryct, ond, Ukynsk, Tyrranisk, Blodgærig, Ulidelig ud i sit Regimente - - . Hand førde sit Regimente icvke udi Low, Skiel oc Ræt, eller lod sig Low oc Ræt undergiffuen som den gode Keyser Theodosius giorde, huilcken der skrifuer all hans oc andre Fyrsters Mact, at vaere aff Low oc Ræt. Men tyckis sig at vaere en mectig Herre, ofuer alt det udi Riget Vaar, oc huer Mand eyede, uanset Low, Skiel, Ræt, Privilegier, Friheder. Der ofuer fands Aarsager nock til, at hand Hans Kongelige Rættigheder til disse Riger, Dannemarck, Sverig oc Norge er forfalden; Saa de dennem med al Ræt hafue sat sig imod hand Vold, Mact, Tyrrani oc dennem igien med anden Øffrighed forsorgit; saa den ene Part hafuer tagit sig til Herre Fredirich den første aff Holsten, den anden Gustaff Erickssøn". 
Wywody Huitfeldta, dyskredytujące Chrystiana II i uzasadniające prawomocność jego obalenia, brzmiały tak przekonywująco, że skorzystał z nich autor relacji o objeździe koronacyjnym Karola IX Sudermańskiego (1609), Petrus Petrejus, szwedzki historyk i dyplomata - w tym przypadku rolę złego tyrana grał Zygmunt III Waza ${ }^{128}$.

Zarzuty pod adresem Eryka Pomorskiego nie były, co prawda, tak drastyczne, bo też nie miał ten władca na sumieniu tyle, co Chrystian, ale i tu znalazł historyk bez trudu uzasadnienia jego obalenia. Jest więc zarzut łamania prawa, przede wszystkim zamach na elekcyjny charakter monarchii i jej „fundamentalne prawa” ${ }^{29}$. Król nie dotrzymywał złożonych obietnic, podburzał chłopów przeciw szlachcie, nakładał nadmierne ciężary, by prowadzić wojny, sprowadzał cudzoziemców na urzędy ${ }^{130}$. Dodatkowym zarzutem autora było „obce” pochodzenie Eryka - był on, jak pisze, pierwszym obcokrajowcem na duńskim tronie i „szkodą dla państwa” (,Riget til skade") ${ }^{131}$. Precyzował, że Eryk odstąpił swym pomorskim kuzynom Rugię (1438), „z czego dobrze widać, że mało zyskaliśmy, biorąc sobie króla z cudzoziemskiego rodu; król Eryk był pierwszym, który chętniej wspierał własną rodzinę niż powiększał królestwo" ${ }^{132}$.

Szkodliwość obcego władcy została dokładniej wyjaśniona przy okazji omawiania fatalnych rządów Adolfa Meklemburskiego w Szwecji (XIV w.). Wśród zarzutów autor wymienia wprowadzanie obcych obyczajów i faworyzowanie cudzoziemców, którzy uciskają ludność, a konkluduje filozoficznie: „Tak ten świat jest urządzony, że każdy chce pozostać przy swoim obyczaju i nie lubi zmian, ani związanych z tym awantur, więc lepiej jest, kiedy kraj zachowuje swoje obyczaje, o ile nie są zbyt złe, niż gdyby miał przyjmować obce, choć lepsze"133.

Wreszcie Krzysztof II, którego ocena i opis, rażące w pierwszym momencie brakiem konsekwencji czy wręcz logiki - okazuje się ujawniać istotne elementy wizji historyka. Krzysztof II został obwołany przez historyka „,najbardziej szkodliwym królem, jakiego kiedykolwiek miało to królestwo" (,den skadeligste Konge som dette Rige nogen tid hafuer haft") ${ }^{134}$. Autor wymieniał liczne jego przewiny: dwukrotnie zbrojnie wystąpił przeciwko swojemu bratu, królowi Danii (Erykowi Menvedowi); sprzymierzał się z obcymi i ściągał ich wojska do kraju, w wyniku czego wielu dobrych ludzi zginęło; wyprawił się na Skanię, gdzie łupił niewinny lud; nakładał ciężary; nie dotrzymywał obietnic i nie przestrzegał prawa; miał podły charakter i wziął sobie do pomocy niewiele lepszego syna ${ }^{135}$. Kiedy zaś usłyszał,

${ }_{128} \AA$. H e m a n s s o n, Karl IX, s. 252-257.

129 DRK I, niepaginowana dedykacja w III części Chronologii; zob. też tamże, s. 817.

130 Tamże, s. 614, 787, 817.

131 Tamże, s. 644.

132 Tamże, s. 802: „Huor er vel at see oc bemercke at vi lidet haffue været tient med at vi tog os Konger aff udlendiske Stamme, Kong Erich vaar den første, som heller haffuer hiulpet deris egen Slect, end Riget formeeret".

133 Tamże, s. 598: „Thi saa er Verdens Løb, at huert Land vil bliffue ved sine Seder, oc kand icke gierne lode Forvandlinger, med mindre det skal komme Bulder oc Fortryckelse aff, saa det er undertiden bedre, at lade it Land beholde sine Seder, naar de ere icke formeget onde, end at mand med ubestand skulle indføre ny Seder, som bedre vaere".

134 Tamże, s. 296, 413.

135 Tamże, s. 411, 461-462. 
że kraj buntuje się przeciw niemu, zabrał najcenniejsze klejnoty koronne i uciekł do Meklemburgii ${ }^{136}$. Wydaje się, że w gruncie rzeczy winy Krzysztofa - zwłaszcza w porównaniu z uczynkami Chrystiana - wcale nie były przesadnie wielkie. A jednak to on miał być najbardziej szkodliwym z królów, a jego rządy historyk uznawał za karę Bożą. Wobec takiego stwierdzenia zaskakuje surowa krytyka tych, którzy władcę obalili. Bo nawet w przypadku króla Krzysztofa II na potępienie zasługiwało to, że szlachta zbuntowała się przeciw królowi, podburzając chłopów i sprzymierzając się z obcymi. Tylko do pewnego stopnia usprawiedliwiają to niecne postępki monarchy oraz fakt, że szlachta występowała w imieniu całego społeczeństwa, bo także Kościół i lud byli z panowania Krzysztofa niezadowoleni ${ }^{137}$. Potępienie pozostaje jednoznaczne, tym bardziej, że bunt ten był częścią nieprzemyślanych działań, a nawet zbrodni, bowiem uprzednio przecież z rąk możnych padł król Eryk Glipping (1286). Huitfeldt nie miał usprawiedliwienia dla królobójstwa. Pisał o tym zawsze z bólem i jednoznacznie potępiał takie uczynki.

Krytykę buntowników zamyka Huitfeldta następującym wnioskiem: „Byłoby lepiej, gdyby zadowolili się tym królem, mimo iż był, jaki był, i pomyśleli, że trzeba ścierpieć króla i władzę, o ile nie są zbyt tyrańskie, zamiast burzyć spokój w kraju, poruszać gmin i wywracać kraj [do góry nogami], [co było] szczególną awanturą. I nasze nieszczęście przypisać możemy tylko naszej głupocie, bowiem długo by trwało zanim Holsztyn zdobył jakąś władzę u nas, gdybyśmy sami sobie go nie ściągnęli na kark. Władcy i książęta z tego winni wyciągnąć naukę, żeby rządzić tak, aby zdobyć uznanie, posłuszeństwo i sympatię poddanych, a nie opór i nienawiść. Poddani natomiast winni wiedzieć, że łatwo rozpocząć intrygi i bunt, ale nie wiadomo, jak one się skończą. Dlatego też nie powinni pochopnie występować przeciw władzy, która pochodzi od Boga"138. Konstruując portret panowania Krzysztofa, Huitfeldt pozostawał po wpływem czternastowiecznego źródła, a mianowicie Kroniki jutlandzkiej (Chronica Jutensis, Jyske Krønike), która ujmowała rzecz w kategoriach religijnych: rządy króla były karą Boską za nieobyczajność i grzechy społeczeństwa, tak więc bunt przeciw nim był w istocie buntem przeciw Bogu ${ }^{139}$. Surowa ocena buntowników wynika jednak także z konsekwencji, jakie ostatecznie spotkały kraj wskutek tych zawirowań: straty terytorialne i podział, prowadzące do dużego rozdarcia, hegemonii hrabiów Szlezwiku i Holsztyna oraz ogromnego zadłużenia państwa. A przecież

136 Tamże, s. 429.

137 Tamże, s. 428-429, 462.

138 Tamże, s. 462-463: „Det hafde været bedre, de hafde nøyedis med denne Konge, huordan han haffde været, oc tenckt vi skulle heller nogenledis fordrage passelige Konger oc Øffrighed naar de icke ere for Tyranske, end forstyrre Landsens Fred, røre Almuen oc vended et heele Rige omkring, med it selsomt Eventyr. - - Oc haffue vi Aarsagen til voris Ulycke ingen anden tilskriffue end voris egen Daarlighed: thi lenge haffde varit før Lante Holsten haffde her fanget Regiering inde, haffde vi icke self lænd os dem paa Halsen. Herrer oc Førster haffue der aff at Lære, at de bruge saadanne Midler udi deris Regiering, som tjene at vinde Undersaatters Gunst, Hyldelse oc Yndets, men icke Vedervillie oc Had. Undersaatterne hafue at lære at it Spil oc Oprør er snart daarligen begynt, men mand veed icke huad Ended et vil tage: huorfore de icke heller lætteligen skulde sætte denem imod deris Øffrighed thi den er aff Gud".

139 J. K a n s tru p, Huitfeldts fremstilling, s. 95. 
w chwili objęcia tronu przez Krzysztofa kraj był wielki, panował nad Estonią, Rugią i Pomorzem, ciesząc się dobrą opinią i szacunkiem ${ }^{140}$.

Zarysowuje się w tym fragmencie sposób myślenia Huitfeldta, w istocie dość klasyczny: poddani mogą występować przeciw władzy i obalać królów, ale jest to możliwe w sytuacji ostatecznej, za którą autor uważa tyrańskie rządy. Władcę obowiązują reguły - jeśli je łamie, Bóg pozwala go obalić. Władza tyrana jest karą za grzechy, ale jeśli udaje się go pozbawić władzy, to znak, że Bóg wybaczył. Jeśli jednak król reguł przestrzega, poddani zobowiązani są do posłuszeństwa ${ }^{141}$. Pewnym nowym elementem jest wszelako kryterium skutków: jeśli państwo miałoby ponieść znaczne straty w wyniku buntu, poddani (także szlachta) winni raczej pogodzić się z rządami tyrana niż ryzykować pomyślność ojczyzny. Dla Huitfeldta nie miało także znaczenia to, że okres rządów Krzysztofa II przyniósł ogromne wzmocnienie możnowładztwa, co zasadniczo przedstawicielowi duńskiej magnaterii powinno się podobać.

Wstrzemięźliwość w ocenie obalenia Krzysztofa, którego Huitfeldt odsądza od czci i wiary, wynika więc z oczywistych skutków: rozbicia kraju i hegemonii szlezwicko-holsztyńskiej. Wobec takiej katastrofy nie dało się sformułować jednoznacznej oceny. Przy późniejszej historii, zwłaszcza w odniesieniu do Eryka Pomorskiego i Chrystiana II, czyli dwóch władców, którzy też zostali zdetronizowani, nie będzie już cienia wątpliwości. Skutki obalenia Eryka i Chrystiana II Huitfeldt widzi raczej jako pozytywy: Dania na tym zyskała, przede wszystkim tak, że w pierwszym przypadku ostatecznie doszła do władzy (po krótkim panowaniu Krzysztofa Bawarskiego) dynastia oldenburska, najlepsza przecież na świecie, a w drugim - ojciec króla Chrystiana III, a potem on sam, ideał władcy. Można więc powiedzieć, że w ocenie wypadków górę wzięła racja stanu: interes państwa, zasada poszanowania prawa i dobro ojczyzny, ale nie mniej istotny był wymóg propagandowy.

Rysuje się jednocześnie jeszcze jeden motyw. W obu piętnasto- i szesnastowiecznych przypadkach przeciw królowi występowała Rada Królewska, której kompetencje nie budziły wątpliwości, a nie siły społeczne (lud czy drobna szlachta). Prawo do oporu przysługuje zatem wybranym, elitom. H. Ilsøe zauważył, że mówiąc o obaleniu Eryka i Chrystiana II, Huitfeldt nie używał nawet słowa ,bunt”, mówił zawsze o ,prawie do oporu” ${ }^{142}$. Mające średniowieczny rodowód ujęcie prawa do oporu jako przysługującego tylko nielicznej grupie, mającej do tego instytucjonalne (a zatem też prawne) umocowanie, utrwaliło się w duńskiej myśli prawno-politycznej - podobne znajdujemy w prawniczym dziele Henrika Ernsta ${ }^{143}$ Catholica iuris z 1634 r.: prawo do obalenia władcy, który łamie prawo Boskie przysługiwać może nie szalonym i lekkomyślnym tłumom, ale „eforom”. Huitfeldt był ostrożny w sprawie udzielania prawa do działania ludziom także w innych publicznych sferach, co widać np. w radach udzielanych Chrystianowi IV w odniesieniu do polityki religijnej: zalecał władcy

140 DRK I, s. 461-462.

141 Tamże II, Kong Hans Krønicke, niepaginowana dedykacja.

${ }^{142}$ H. I 1 s ø e, En redegørelse, s. 53.

${ }^{143}$ Henrik Ernst (1603-1665), niemiecki znawca prawa i filolog, od 1626 r. na służbie Chrystiana IV, wykładowca i profesor Akademii w Sorø, nauczyciel synów możnowładców i księcia Waldemara Chrystiana. 
pilnować, by żadne zmiany w ceremoniach religijnych nie były wprowadzane przez prywatne osoby, bowiem: ,Jeśli taką wolność przyznać prywatnym osobom, każdy będzie znajdował swoje własne zwyczaje i skutkiem takich zmian będzie zróżnicowanie, wymieszanie i chaos"144. Historyk miał zapewne w pamięci wydane przez Fryderyka II w 1580 r. rozporządzenie zakazujące rozpowszechniania powstałej niedawno augsburskiej Formuły zgody - król uzasadniał tę decyzję m.in. tym, że może ona zburzyć jedność, panującą dotąd w duńskim Kościele ${ }^{145}$. Chwaląc takie rozwiązania, historyk odrzucał nadrzędność idei wolności. Aktywizacja niższych warstw społecznych na ogół miała postać wykorzystywania przez szlachtę chłopów do walki przeciw królowi, co sprowokowało historyka do takiej uwagi: „Porozumienia między możnymi i gminem, którzy różnią się swym majątkiem, zawsze były nieszczęśliwe. Cóż powiedzieć o takich sojuszach, które teraz się zdarzają. Historia uczy, że wojna jest karą dla obu stron, a ten, kto bez przyczyny ją zaczyna, źle kończy"146. Bez wątpienia była to aluzja wojny hrabskiej w Danii.

Przeciwieństwem tyrana i zbrodniarza jest władca idealny. Jego charakterystyka została przedstawiona na dwa sposoby: w rozważaniach teoretycznych (głównie dedykacjach) oraz, bardziej konkretnie, w opisach „dobrych” królów Danii. Mówiąc ogólnie o cnotach władcy, Huitfeldt wymieniał następujące cechy, ale też metody sprawowania władzy: rządzić trzeba łagodnością, a nie strachem, ten bowiem rodzi nienawiść; kto opiera swą władzę na twierdzach, a nie na bojaźni Bożej, sprawiedliwości i miłości ludu, szykuje sobie zgubę i kończy jak Eryk Pomorski i Chrystian II; miłość ludu jest fundamentem rządów, a „bez sprawiedliwości nie ma państwa” - taką maksymę umieścił historyk na stronie tytułowej kroniki króla Hansa. Jak widać, zdecydowanie bliżej Huitfeldtowi do Erazma z Rotterdamu, dla którego działania polityczne musiały zawsze pozostawać zgodne z chrześcijańską etyką, niż do Macchiavellego, który mniemał, że nie da się ich na ogół pogodzić z zasadami moralnymi obowiązującymi zwykłych ludzi, a dla władcy zawsze najbezpieczniej jest, jeśli poddani raczej się go boją niż miłują. W podkreślanie znaczenia narodowego interesu i rodzimości wpisuje się wyrastająca z wielowiekowej tradycji rada, by nie powierzać urzędów obcym ${ }^{147}$. Pacyfizm doszedł do głosu w nieoczekiwanym i dość odosobnionym komentarzu w związku z opisem wojen pod koniec XII w.: „Gdyby królowie i książęta pomyśleli, że przyjdzie im zdać rachunek ze swoich rządów, z tego jak dbali o lud Boży, nie walczyliby o kraje i państwa tak, jak to czynią: lud należy do Boga, a nie [króla]"148. Komentarz, pierwszy tego typu w dziele (choć we fragmencie pisanym przecież pod koniec pracy), nasuwa myśl o zapożyczeniu, ale

${ }^{144}$ DRK II, niepaginowana dedykacja w opisie panowania Chrystiana I: „Thi skulle slig Frihed privat Personer stedis, da skulde huer finde paa sin Skick oc bleff paa det sidste aff saadan Forandering en stor Atskillighed og Forblendelse oc Chaos".

${ }^{145}$ Dansk litteratur historie, t. II, s. 32.

${ }^{146}$ DRK I, s. 294-295.

147 Tamże II, niepaginowana dedykacja w opisie panowania Chrystiana I; tamże, niepaginowana dedykacja w opisie panowania Hansa; tamże I, s. 778.

148 Tamże I, s. 157: „Dersom Konger oc Førster vilde tencke at de gang skulde giøre Regenskab for deris Regimente, huorledis de Guds Almue forestandet haffue da stridde de icke om Lande oc Riger som de giøre: Folcket hører Gud til icke hannem”. 
nie jest to w gruncie rzeczy zbyt istotne - skoro autor go umieścił, musiał się z tym poglądem utożsamiać. Niewątpliwie słowa te pasowały do człowieka doświadczonego, znajdującego się u schyłku jego życia, tym bardziej, że Huitfeldta, podobnie jak wielu magnatów duńskich tych czasów, cechowała wyraźna niechęć do wojny jako sposobu rozwiązywania problemów politycznych.

W opisie konkretnych „dobrych” królów pojawiają się określenia konwencjonalne, czerpane z wielkiego zasobu europejskiego piśmiennictwa różnych epok - cechy, które przypisywano Salomonowi, Dawidowi, różnym cesarzom rzymskim, Karolowi Wielkiemu czy królowi Arturowi. Niemal wyjęta z tego repozytorium jest charakterystyka króla Eryka Menveda - mocno zresztą przesłodzona, skoro należało go skonfrontować z następcą, czyli złym Krzysztofem II, ale też wierna średniowiecznym źródłom, które przedstawiały czasy panowania tego władcy jako „wiek złoty”149. Tak więc król, jeden z najlepszych, jakich miała Dania, kochał Boga i sprawiedliwość, wspierał dobrych i karał złych, dbał o królestwo i nie pozwalał naruszać jego praw, karał surowo szlachtę i lud, ale miał ku temu powody ${ }^{150}$. Dobry władca zazwyczaj otrzymuje liczne, dość konwencjonalne przymiotniki: „dobry i pobożny” (,god oc from”), cnotliwy, bogobojny (dydelig, Gudsfrygtig). Powodem do pochwały są przywileje i nadania dla Kościoła ${ }^{151}$ oraz przestrzeganie prawa. Król Olaf, syn Małgorzaty I, który zmarł w wieku 16 lat i jako żywo sam nie rządził, otrzymuje pochwałę za to, że zawsze miał przy sobie kogoś, kto mu doradzał - przy tej okazji pada też informacja, kto w tym czasie był kanclerzem Królestwa - ale też za przywileje dla miast i za połączenie unią Danii i Norwegii, „oby Bóg to zachował” („Gud lade saalenge bliffue") $)^{152}$. Równie mechaniczna jest pochwała Krzysztofa Bawarskiego, który był „dobry i pobożny”, ale niewiele da się o nim powiedzieć, bo krótko panował ${ }^{153}$. Pozytywna ocena Oldenburgów wynika z opisu całego panowania, zaś poszczególni władcy charakteryzowani są oszczędnie. Chrystian I „był pobożnym, łagodnym, bogobojnym i pracowitym panem i królem i zalicza się go dobrych królów, którzy panowali w tym królestwie. Od niego wywodzi się dynastia Oldenburgów, która teraz panuje. Oby jego następcy wzięli sobie jego przykład do serca, naśladując życie i czyny"154. Na wielką pochwałę zasłużył sobie ten król założeniem uniwersytetu w Kopenhadze, dzięki czemu ,uwolnił naszą ojczyznę od ciemnoty i stanu barbarzyństwa" ${ }^{155}$. Fryderyk I z kolei powinien był sławiony i zapamiętany za zniesienie szkodliwych i bezprawnych recesów Chrystiana II $^{156}$ oraz za nadanie szlachcie pełni władzy nad chłopami ${ }^{157}$. Chrystian III - także wzór do naśladowania - nie ruszał się w objazd po kraju bez 4-5 członków Rady Królestwa ${ }^{158}$.

\footnotetext{
${ }_{149}$ J. K a n s tru p, Huitfeldts, s. 97.

150 DRK I, s. 410.

151 Tamże, s. 157, 643.

152 Tamże, s. 573.

153 Tamże, s. 841.

154 Tamże II, s. 960.

155 Tamże, s. 948: ,at vort Fæderne Land er befrit fra Mørkhed oc it Barbariske Vesen”.

156 Tamże, niepaginowana dedykacja w opisie panowania Hansa.

157 Tamże, s. 1252.

158 Tamże, niepaginowana dedykacja w opisie panowania Chrystiana III; tamże, s. 1555.
} 
Wydaje się, że najwięcej sympatii historyka budził król Hans, którego opis jest najbardziej rozbudowany. Być może było to skutkiem tego, że w odniesieniu do tego władcy Huitfeldt dysponował sporządzoną przez Hansa Svaninga charakterystyką, która mogła wtedy funkcjonować jako swoisty kanon, została bowiem upubliczniona, także za granicą ${ }^{159}$. Hansowi zatem przydzielono cechy, które wiązano z osobą władcy pożądanego i które zalecano przyswoić sobie młodemu Chrystianowi IV. Król Hans odznaczał się przymiotami charakteru: był dobrym, życzliwym wobec ludzi człowiekiem i praktykował chrześcijańskie cnoty. Dzięki temu też, mimo iż prowadził nieustanne wojny i nakładał ciężary na ludność, poddani nie przestali go kochać i zawsze byli gotowi stawić się na wezwanie. Co ważniejsze, prowadził dobrą politykę. Mądry i bystry, mógł bez trudu sam rządzić, ale zawsze przy ważnych sprawach pytał o zdanie wszystkich członków Rady Królestwa i postępował za wolą większości. Do tego był przywiązany do tradycyjnych, duńskich potraw i stroju, pił duńskie piwo i nosił u boku, wzorem przodków, duński miecz. Prowadził życie skromne, wedle starego obyczaju ,i nie chciał przyjmować nowych zwyczajów, jak to (niestety) dziś ma miejsce” (,oc vilde icke gierne tage paa nogen ny Vis oc Skick, som nu (dis værre) meget brugeligt er" $)^{160}$. Łączył zatem trzy fundamentalne cechy: dobroć charakteru, przywiązanie do duńskości i narodowych tradycji oraz szacunek dla pozycji magnaterii.

Przy swym niekwestionowanym rojalizmie, Huitfeldt nie wystawiał jednak królom laurek - w wielu przypadkach (jest to reguła wobec władców dawniejszych) wskazywał na błędy i słabości, choć stylistykę ocen cechuje oględność. Król Waldemar II, autor wielu sukcesów militarnych (choć historyk chwali go przede wszystkim za kodyfikację prawa), grzeszył rozwiązłym trybem życia. Charakterystyczne, że na dobrą opinię zasłużył wtedy, kiedy załamany klęskami uspokoił się, przestał wojować, zmniejszył podatki i rządził sprawiedliwie ${ }^{161}$. Zdrady małżeńskie miał na swoim koncie także król Waldemar Odnowiciel, który do tego łamał przywileje szlacheckie ${ }^{162}$. Chrystian I, przyznaje historyk, nie znał łaciny, czym wprawił w zdumienie papieża ${ }^{163}$. Hans cierpiał na melancholię i czasem dziwnie się zachowywał, zdradzał swą królewską małżonkę i nienawidził serdecznie Stena Sture i Hemminga Gadha ${ }^{164}$. Życzliwości autora wobec Małgorzaty nie zmienił fakt, że twardą ręką rządziła szlachtą i dążyła do wzmocnienia Korony, np. wykupując szlacheckie majątki ${ }^{165}$.

Stworzone przez Huitfeldta dzieło ukazuje pewną wizję dziejów, która łącząc właściwe dla epoki myślenie, zachowuje regionalne cechy skandynawskie. Jednocześnie jest to wizja, w której uzasadnienie znajdują najważniejsze cechy ustrojowe

159 Tzw. Kronika Jana była częścią polemicznego dzieła: Refutatio calumniarum cuiusdam Joannis Magni Gothi - - Huic accessit chronicon sive historia Joannis regis Daniae in declarationem eiusdem refutationis, wydanego w $1561 \mathrm{r}$.

${ }^{160}$ DRK II, niepaginowana dedykacja w opisie panowania Hansa; tamże, s. 1091.

161 Tamże I, s. 184, 187, 198, 206.

162 Tamże, s. 554.

163 Tamże II, s. 942.

164 Tamże, s. 1009, 1048, 1061. Hemming Gadh (zm. 1520) to szwedzki duchowny, polityk i wojskowy, jeden z głównych polityków w Szwecji czasów Sturów; Sten Sture (1440-1503), naczelnik państwa, przywódca antyduńskej opozycji, szwedzki bohater narodowy.

165 Tamże I, s. 643. 
systemu rządów szlachty w takim wydaniu, jakie rozwinęło się w Danii w drugiej połowie XVI w. Za przynależne do renesansowego ujęcia dziejów można uznać to, że Kronika jest historią narodową, podkreślającą rolę i znaczenie duńskiego punktu widzenia, a zarazem nawołującą do zrozumienia wagi rodzimości i narodowych interesów. Legitymizację istnienia znajduje we własnych dziejach, a nie we wpisaniu ich do uniwersalistycznego porządku. Cechuje ją świecka perspektywa i ukazanie dziejów jako rezultatu działań ludzi. Odwołuje się do klasycznego konceptu historii jako „nauczycielki życia”, nakazując jej realizować dydaktyczne (,mistrzyni polityki”) oraz, w mniejszym stopniu, moralizatorskie cele. W Kronice odzywa się poczucie zmienności dziejowej, szesnastowiecznego historyzmu, a autor krytycznie odnosi się do dziejów bajecznych. Jest też reprezentantem renesansu raczej północnoeuropejskiego, który - jak Erazm z Rotterdamu - zawsze ostatecznie nad autorytet klasycznych, rzymskich pisarzy stawiał Stary i Nowy Testament ${ }^{166}$. Stąd koncepcja oceny działań politycznych, odwołująca się nie do skuteczności, ale do zasad chrześcijańskiej etyki, a także bardzo nikłe zakorzenienie w starożytnych wzorcach, zarówno w odniesieniu do tradycji historiograficznej, jak i wywodów genetycznych. Zastosowanie języka narodowego odsuwa co prawda autora od dominującej w epoce tendencji klasycznych i powrotu do starożytnej, czystej łaciny, ale nie jest to w istocie jednoznaczne z odejściem od renesansowego dziejopisarstwa - zwłaszcza w Europie Północnej, $\mathrm{w}$ zgodzie $\mathrm{z}$ występującymi $\mathrm{w}$ tych czasach tendencjami nacjonalistycznymi, stosowanie języka narodowego uważano za dowód patriotyzmu ${ }^{167}$. W tym czasie nie tylko wielu duńskich uczonych (np. Vedel) kultywowało język narodowy, ale rosło też zainteresowanie językiem staronordyckim.

Jednocześnie trudno mówić o spełnieniu tu jakiegoś modelowego ujęcia - nie jest to historia należąca do nurtu retoryczno-humanistycznego, ani do nurtu protestanckiej polemiki, ani tym bardziej do pisarstwa erudycyjnego. Pod wieloma względami jest to dzieło tradycyjne, silnie nawiązujące do średniowiecznych wzorów. Typ narracji trudno nazwać retorycznym, bo tylko we fragmentach Huitfeldta „się czyta” - bywa za to nużący, jak średniowieczny rocznik. Męczy też natłok dokumentów, choć z drugiej strony jest to jakiś dowód na intuicyjne wyczucie źródła - te cechy, wydaje się, zbliżają autora do ówczesnego antykwaryzmu. Choć Huitfeldt w bardzo tradycyjny sposób realizował heroistyczną koncepcje wyjaśniania zdarzeń dziejowych - głównymi aktorami pozostają monarchowie i możni - dostrzegał też rolę niższych stanów, okazując w tym pewną niezależność wobec własnego wzorca, u Saksona Gramatyka bowiem, jak to $\mathrm{w}$ średniowiecznej historii, lud praktycznie nie istniał.

Szlachecka perspektywa ujęcia dziejów ojczyzny realizuje się na kilka sposobów. Pierwszym elementem jest ocena władców, która jest funkcją ich stosunku do szlachty, a ściślej Rady i magnatów. W duńskiej historiografii czasów rządów szlachty, czyli do 1660 r., dominował obraz władcy modelowego, którym był Chrystian III, skonfrontowany z jego antytezą - Chrystianem II. Tylko władca harmonijnie współpracujący z magnatami i szanujący prawo, głównie przywileje całego stanu, zasługuje na ocenę pozytywną. Taki pogląd łączy się z konsekwentnym rojalizmem, dając

166 Dansk litteratur historie, t. II, s. 44.

167 C. H i r s c h i, The Origins, s. 108-109; M. A. N i e l s e n, Norse Philology Anno 1570, Nordic Journal of Renaissance Studies 2008, s. 6. 
w efekcie afirmację modelu ustrojowego opartego na zasadzie równowagi między Koroną a Radą. Modelu oligarchicznego i arystokratycznego, a nie demokratycznego. Huitfeldt wstrzemięźliwie odnosił się do nadmiernej aktywności politycznej szlachty oraz nie miał najmniejszej skłonności do apologizowania jej roli w dziejach. Drugim kluczowym elementem szlacheckiej perspektywy jest pogląd, że monarchia duńska od zawsze miała charakter elekcyjny, co czyni ze szlachty, a później magnatów, najistotniejszy czynnik państwotwórczy, a zarazem nosiciela suwerenności. Elekcyjność tronu jest także gwarancją wolności. System taki jest bardziej naturalny, lepiej osadzony w wielowiekowej tradycji, jako że - zdaniem historyka - to powstanie monarchii dziedzicznych jest skutkiem procesów historycznych, które na szczęście (jak oceniał) Danię ominęły. Ale i ustrój monarchii elekcyjnej ulegał ewolucji. Zmieniła się forma elekcji, z czasem prawo to przeszło bowiem w ręce grupy „,mądrych i doświadczonych".

W rezultacie ukształtowała się wizja, w świetle której system współrządów wybranego, ale mającego Boską sankcję, monarchy z arystokratycznymi doradcami jest najlepszym sposobem zagwarantowania ojczyźnie pomyślności. Magnaci reprezentują bowiem to, co w społeczeństwie najlepsze: mądrość, roztropność, patriotyzm. Zarazem przyjmuje się, że nie ma rozbieżności między nimi a resztą szlachty. Proponowana koncepcja dziejów była atrakcyjna dla magnaterii, bowiem ukazywała i sankcjonowała jej rolę, ale była też bliska mentalności całej ówczesnej szlachty, która ewoluowała od stanu rycerskiego do szlachty ziemiańskiej, z upodobaniem zajmującej się gospodarowaniem, karierą urzędniczą czy aktywnością kulturalną. Wojenne wyczyny chętniej zostawiano przodkom, a zalecany model polityki miał być pokojowy, oparty na prawie i rodzimych wartościach.

\section{BIBLIOGRAFIA}

Bömelburg H.-J., Polska myśl humanistyczna a humanistyczna historia narodowa (1500-1700), przekł. Z. Owczarek, Universitas, Kraków 2011.

Ciesielski Z., Dzieje kultury skandynawskiej, t. I, Gdańsk 2016.

Cotta-Schønberg M. von, Danmarksbillede hos en renæssancehumanist, Æneas Silvius Piccolomini (Pius II), w: Renæssancen i svøb. Dansk renæssance i europæisk belysning 1450-1550, Odense 2008.

Daa L., Nogle Bemærkninger om Historieskriveren Albert Krantz, Historisk Tidsskrift, ser. 2, t. 5, 1886.

Damsholt T., Den nationale magtstat 1560-1760, w: Danmarks historie, t. X, København 1992.

Dansk litteratur historie, t. II, Gyldendal 1984.

Evans J., A History of the Society of Antiquaries, Oxford 1956.

Friis A., Nogle Betragtninger over Arild Huitfeldt og Danmarks Riges Krønike, w: Til Knud Fabricius, 13. August 1945, Kjøbenhavn 1945.

Grafton A., Worlds made by Words. Scholarship and Community in the Modern West, Harvard 2011.

Grzybowski S., Prawo oporu - dylemat szekspirowski, w: Król a prawo stanów do oporu, Kraków 2010.

Hermansson $\AA$., Karl IV och ständerna. Tronfrågan och författningsutvecklingen i Sverige 1598-1611, Uppsala 1962

Hirschi C., The Origins of Nationalism. An Alternative History from Ancient Rome to Early Modern Germany, Cambridge University Press 2012.

Huitfeldt A., Danmarckis Rigis Krønicke, t. I-II, Kiøbenhaffn 1652. 
Ilsøe H., Arild Huitfeldts Krønike, konfronteret med Anders Sørensen Vedel og eftertiden, Fund og Forskning, 14, 1967.

Ilsøe H., En redegørelse for Arild Huitfeldts alment litterære læsning og åndhistorisk baggrund således som det kan læses ud af hans fortaler til Danmarks Riges Krønike og hans kommenterende bemærkninger i selve dennes tekst, København 1955.

Ilsøe H., Historisk censur i Danmark indtil Holberg, Fund og Forskning 20, 1973.

Jørgensen E., Historieforskning og Historieskrivning i Danmark indtil Aar 1800, København 1931.

Kanstrup J., Huitfeldts fremstilling af Christoffer II's tilbagekomst til Danmark, Historisk Tidsskrift, ser. 12, t. 6, 1972.

Kaspersen S. i in., Dansk litteratur historie, t. I, Gyldendal 1984.

Larsson L.O., Gustaw Waza. Ojciec państwa szwedzkiego czy tyran?, przekł. W. Łygaś, PIW, Warszawa 2009.

Mierzwa E., Historia historiografii, t. II, Warszawa 2007.

Nielsen M.A., Norse Philology Anno 1570, Nordic Journal of Renaissance Studies 2008.

Nielsen L., Joachim Moltke, w: Dansk biografisk Leksikon, Gyldendal 1979-1984, online: $<$ https://biografiskleksikon.lex.dk/Joachim_Moltke $>$.

Pomian K., Przeszłość jako przedmiot wiary, Warszawa 2009.

Rian Ø., Historie i tvangstrøye. Kongemakt og historieformidling i Danmark-Norge 15361814, Historisk tidsskrift [norw.] 92, 2013.

Rørdam H.F., Historieskriveren Arild Huitfeldt, Danmarks Riges Kansler og Raad, Skoleherre for Herlufsholm, Kjøbenhavn 1896.

Skovgaard-Petersen K., Historiography at the Court of Christian IV (1588-1648). Studies in Latin Histories by Johannes Pontanus and Johannes Meursius, Copenhagen 2002.

Vedel A.S., Fortale, w: Den danske Krønike af Saxo Grammaticus, ovesat af Anders Sørensen Vedel, wyd. C.F. Wegener, Kiøbenhavn 1851.

Vedel A.S., Om Den Danske Krønicke at bescriffue, w: Humanister i Jylland, red. E. Munksgaard, København 1959.

Vinilandicus P.A., Nordens gotiske storhedstid, Syddansk universitetsforlag, Odense 2012.

Zakrzewski A., Prawo oporu w Wielkim Księstwie Litewskim od wieku XIV do XVIII, w: Król a prawo stanów do oporu, Kraków 2010.

\section{Arild Huitfeldt's aristocratic vision of the national history of Denmark}

\section{Summary}

In the wake of 16th century growth of nationalism, interest in history was flourishing. In Denmark at that time several internal (the legitimization of the Oldenburg dynasty and the political system) and external (imperial competition with Sweden) needs made the task of presenting the modern national history an urgent issue. Despite many efforts the Crown did not manage to fullfil the program of offering a „continuation of Saxo”. Nevertheless, the turn of the century saw such a book, the vernacular Chronicle of Denmark in 9 volumes, being produced by the Chancellor of the Realm, Arild Huitfeldt. Although it can be seen as quite close to the renaissance model of historical writing, mainly by presenting a pragmatic, didactic vision of history and by focusing on national, secular past, it cannot be seen as a part of rhetorical narrative, because of its traditional annalistic character. Huitfeldt provided the reader with a vision of history of the kingdom of Denmark in which the role of magnates (aristocracy) was emphasized, and the monarchy ,,always" had an elective character. In this way he provided ideological and historical justification for the existing political system, based on the balance between the king and the magnates, and on the division of power between the Crown and the Privy Council. 